(C) 2022, The Authors. Published by Elsevier Inc. and Fass Inc. on behalf of the American Dairy Science Association ${ }^{\circledR}$. This is an open access article under the CC BY license (http://creativecommons.org/licenses/by/4.0/).

\title{
Supplementation of Ascophyllum nodosum meal and monensin: Effects on diversity and relative abundance of ruminal bacterial taxa and the metabolism of iodine and arsenic in lactating dairy cows
}

\author{
L. H. P. Silva, ${ }^{1 *}$ S. F. Reis, ${ }^{1} \dagger$ A. T. O. Melo, ${ }^{1} \ddagger$ B. P. Jackson, ${ }^{2}$ and A. F. Brito ${ }^{1} \S$ \\ ${ }^{1}$ Department of Agriculture, Nutrition and Food Systems, University of New Hampshire, Durham 03824 \\ ${ }^{2}$ Department of Earth Sciences, Dartmouth College, Hanover, NH 03755
}

\begin{abstract}
Previous research has shown that the brown seaweed Ascophyllum nodosum (ASCO) has antimicrobial and antioxidant properties and also increases milk I concentration. We aimed to investigate the effects of supplementing ASCO meal or monensin (MON) on ruminal fermentation, diversity and relative abundance of ruminal bacterial taxa, metabolism of I and As, and blood concentrations of thyroid hormones, antioxidant enzymes, and cortisol in lactating dairy cows. Five multiparous ruminally cannulated Jersey cows averaging (mean \pm standard deviation) $102 \pm$ $15 \mathrm{~d}$ in milk and $450 \pm 33 \mathrm{~kg}$ of body weight at the beginning of the study were used in a Latin square design with $28-\mathrm{d}$ periods ( $21 \mathrm{~d}$ for diet adaptation and $7 \mathrm{~d}$ for data and sample collection). Cows were fed ad libitum a basal diet containing (dry matter basis) 65\% forage as haylage and corn silage and $35 \%$ concentrate and were randomly assigned to 1 of the following 5 dietary treatments: $0,57,113$, or $170 \mathrm{~g} / \mathrm{d}$ of ASCO meal, or $300 \mathrm{mg} / \mathrm{d}$ of MON. Supplements were placed directly into the rumen once daily after the morning feeding. Diets had no effect on ruminal $\mathrm{pH}$ and $\mathrm{NH}_{3}{ }^{-}$ $\mathrm{N}$ concentration, which averaged 6.02 and $6.86 \mathrm{mg} /$ $\mathrm{dL}$, respectively. Total volatile fatty acid concentration decreased linearly in cows fed incremental amounts of ASCO meal. Supplementation with ASCO meal did not change the ruminal molar proportions of volatile fatty acids apart from butyrate, which responded quadratically with the lowest values observed at 56 and $113 \mathrm{~g} / \mathrm{d}$ of ASCO supplementation. Compared with the control
\end{abstract}

Received August 3, 2021.

Accepted January 5, 2022.

*Present address: Department of Agriculture and Food Science, Western Kentucky University, Bowling Green, KY 42104.

$\dagger$ Present address: DSM Animal Nutrition and Health, São Paulo, SP, Brazil 04543-907.

$\ddagger$ Present address: Inova Genética LTDA., Cristalina, Goiás, Brazil 73850-000.

§Corresponding author: andre.brito@unh.edu diet or diets containing ASCO meal, cows fed MON showed greater molar proportion of propionate. Diets did not affect the $\alpha$ diversity indices Shannon, Simpson, and Fisher for ruminal bacteria. However, feeding incremental levels of ASCO meal linearly decreased the relative abundance of Tenericutes in ruminal fluid. Monensin increased the relative abundance of the $C A G$ : 352 bacterial genus in ruminal fluid compared with the control diet. Linear increases in response to ASCO meal supplementation were observed for the concentrations and output of I in serum, milk, urine, and feces. Fecal excretion of As increased linearly in cows fed varying amounts of ASCO meal, but ASCO did not affect the concentration and secretion of As in milk. The plasma activities of the antioxidant enzymes and the serum concentrations of thyroid hormones did not change. In contrast, circulating cortisol decreased linearly in diets containing ASCO meal. The apparent total-tract digestibilities of dry matter, organic matter, and crude protein increased linearly with ASCO meal, but those of neutral and acid detergent fiber were not affected. In summary, feeding incremental amounts of ASCO meal decreased serum cortisol concentration, and increased I concentrations and output in serum, milk, feces, and urine.

Key words: ionophore, kelp meal, ruminal microbiota, seaweed

\section{INTRODUCTION}

There is a growing interest in incorporating seaweeds in ruminant diets motivated by the effects of algal feeds on reducing enteric methane emissions while improving animal health (Allen et al., 2001; Makkar et al., 2016; Roque et al., 2019). The dried meal obtained from the brown seaweed Ascophyllum nodosum (ASCO) and commercialized as kelp meal is extensively fed in organic dairies across the United States (Hardie et al., 2014; Antaya et al., 2015; Sorge et al., 2016a; Snider et al., 2021). In addition to a wide spectrum of bioactive compounds [e.g., antioxidants, PUFA, and phlorotan- 
nins (PT)], ASCO is rich in micro- and macrominerals, particularly I and Na (Evans and Critchley, 2014; Antaya et al., 2015, 2019; Makkar et al., 2016). Seaweeds can also accumulate As, a potentially toxic metalloid (Monagail et al., 2018). However, As concentration in ASCO appears to be lower than that found in other macroalgae species such as Laminaria digitata and Fucus vesiculosus (Taylor and Jackson, 2016). We are not aware of studies in which the metabolism of As, including its concentration and output in milk, urine, and feces, was investigated in cows fed ASCO meal. In addition, there is limited research on the effects of ASCO meal on I utilization in lactating dairy cows.

In vitro studies showed that ASCO extracts have antibacterial properties due to the presence of $\mathrm{PT}$ in algal tissues (Wang et al., 2009b; Jiménez et al., 2010). Wang et al. (2009a) observed a selective effect of ASCO-PT on the growth of purified ruminal bacteria in batch culture. Specifically, ASCO-PT inhibited growth of the cellulolytic species Fibrobacter succinogenes and Ruminococcus albus and stimulated that of the noncellulolytic species Selenomonas ruminantium, Ruminobacter amylophilus, and Prevotella bryantii. This shift in bacterial species affected ruminal fermentation as evidenced by a linear decrease in the molar proportion of acetate when PT was increased from 0 to $500 \mu \mathrm{g} / \mathrm{L}$ in vitro (Wang et al., 2009a). Recently, Zhou et al. (2018) reported linear decreases in the ruminal concentrations (copies/g of DM) of archaea and bacteria with feeding ASCO meal (up to $5 \%$ of the diet DM) to rams, as well as a linear increase in protozoal numbers (cells/ $\mathrm{mL})$. Despite the antimicrobial effect of ASCO meal, the levels used (i.e., $>1 \%$ of the diet DM) in previous studies (e.g., Belanche et al., 2016a; Zhou et al., 2018) may not be practically feasible due to the risk of excess I intake and impairment of thyroid function. Based on our previous research (Antaya et al., 2015, 2019), the concentration of I in ASCO meal averaged $774 \mathrm{mg} / \mathrm{kg}$ of DM. Using average values for DMI of $17.2 \mathrm{~kg} / \mathrm{d}$ and BW of $427 \mathrm{~kg}$ in Jersey cows (Brito and Silva, 2020) and $5 \%$ inclusion of ASCO meal in diet DM (Belanche et al., 2016a; Zhou et al., 2018), intake of I would be $666 \mathrm{mg} / \mathrm{d}$, which is about $10,000 \%$ greater than the $6.41 \mathrm{mg}$ of I required daily by lactating cows $(1.5 \mathrm{mg}$ of $\mathrm{I} / 100 \mathrm{~kg}$ of BW; NRC, 2001). Iodine toxicity (Olson et al., 1984) and enlargement of the thyroid gland (Ong et al., 2014) have been reported to occur with $500 \mathrm{mg} / \mathrm{d}$ of I intake and 7.5 to $12.5 \mathrm{mg}$ of I intake/100 kg of BW in dairy cows, respectively. Therefore, the effect of ASCO meal supplementation on ruminal fermentation profile and microbiota diversity should be tested within the range $(\leq 1 \%$ of the diet $\mathrm{DM})$ fed in experiments done with lactating dairy cows (e.g., Pompeu et al.,
2011; Antaya et al., 2015, 2019) and recommended by seaweed suppliers.

The ionophore monensin (MON) has been largely used in ruminant diets as a feed additive to improve feed efficiency and animal health through inhibition of gram-positive bacteria (Duffield et al., 2008b; Schären et al., 2017). However, there are increasing concerns and consumer pressure against the use of antibiotics as feed additives in livestock diets, which justifies research using alternative antimicrobials such as ASCO. Previous in vitro studies revealed that ASCO extracts were more potent against gram-positive than gram-negative bacteria (Wang et al., 2009a; Jiménez et al., 2010), thus resembling the action of MON. Furthermore, ASCO meal supplementation reduced the concentration of blood cortisol during cold (Antaya et al., 2015) and hot (Allen et al., 2001) temperatures possibly associated with ASCO's thermoregulatory and antioxidant effects (Allen et al., 2001), but additional research is warranted.

We hypothesized that ASCO meal would change the diversity and relative abundance of ruminal bacterial taxa mediated by the antimicrobial activity of ASCOPT. It was also hypothesized that feeding incremental amounts of ASCO meal would result in linear increases in the concentrations and output of I and As in milk, urine, and feces. Our objective was to evaluate the effects of ASCO meal and MON supplementation on ruminal fermentation profile, diversity and relative abundance of bacterial taxa in ruminal fluid, metabolism of I and As, and concentrations of blood metabolites and hormones in lactating Jersey cows.

\section{MATERIALS AND METHODS}

All experimental procedures were reviewed and approved by the University of New Hampshire Institutional Animal Care and Use Committee (IACUC protocol \#140803). The experiment was carried out at the University of New Hampshire Fairchild Dairy Teaching and Research Center (Durham) from June 23 to November 10, 2015. Ruminal cannulation surgeries were performed approximately $60 \mathrm{~d}$ before the beginning of the experiment.

\section{Animals, Experimental Design, and Diets}

Five multiparous ruminally cannulated Jersey cows averaging (mean $\pm \mathrm{SD}$ ) $102 \pm 15 \mathrm{DIM}, 450 \pm 33 \mathrm{~kg}$ of BW, $2.80 \pm 1.9$ parity, and $27.2 \pm 2.8 \mathrm{~kg} / \mathrm{d}$ of milk at the beginning of the study were randomly assigned to treatment sequences in a $5 \times 5$ Latin square design. Each experimental period lasted $28 \mathrm{~d}$, with $21 \mathrm{~d}$ for 
diet adaptation and $7 \mathrm{~d}$ for data and sample collection. Treatments consisted of $0 \mathrm{~g} / \mathrm{d}$ (control), $57 \mathrm{~g} / \mathrm{d}$, $113 \mathrm{~g} / \mathrm{d}$, and $170 \mathrm{~g} / \mathrm{d}$ of ASCO meal (Tasco; Acadian Seaplants Ltd.), and $300 \mathrm{mg} / \mathrm{d}$ of MON. A medicated pellet feed (Poulin Grain Inc.) was fed $(113 \mathrm{~g} / \mathrm{d})$ to deliver $300 \mathrm{mg}$ of monensin sodium daily. Treatments were placed directly into the rumen immediately after the morning feeding at $0700 \mathrm{~h}$ throughout the duration of the study.

A basal diet containing (DM basis) $40.8 \%$ mixed legume-grass silage, $25.5 \%$ corn silage, and $33.7 \%$ of a ground corn-soybean meal-based concentrate was offered as a TMR twice a day at 0700 and $1700 \mathrm{~h}$. A Super Data Ranger mixer (American Calan Inc.) was used to record the weight of dietary ingredients and deliver the TMR. Orts were collected daily before the afternoon feeding and weighed using the Super Data Ranger mixer. The amount of TMR was adjusted daily to yield about $10 \%$ orts. Cows were housed in a freestall barn in a pen equipped with electronic recognition Calan doors (American Calan Inc.) and had free access to water throughout the 112-d experiment.

\section{Feed Sampling and Analyses}

Samples of silages, TMR, and orts were collected once per week during the study and polled by period. Orts and TMR samples were taken daily and pooled by week during each sampling period (d 21-28). Ground corn, soybean meal, roasted soybean, monensin sodium pellet, and ASCO meal samples were collected on d 22 of each experimental period. All feeds and orts were dried in a forced-air oven at $55^{\circ} \mathrm{C}$ (VWR Scientific) for approximately $48 \mathrm{~h}$, ground to pass through a 1-mm screen (Wiley mill; Arthur H. Thomas Co.), and shipped to Dairy One Forage Testing Laboratory (Ithaca, NY) and Dartmouth College Trace Element Laboratory (Hanover, NH) for wet chemistry analyses.

Ground samples of feeds were analyzed for DM, ash, total N, $\alpha$-amylase treated, ash-free NDF, ADF, ether extract, minerals, soluble CP, NDIN, ADIN, ADL, ethanol-soluble carbohydrates, and starch following the wet chemistry procedures used by Dairy One Forage Testing Laboratory (https://dairyone.com/download/ forage-forage-lab-analytical-procedures/?wpdmdl = 13889\&refresh $=5$ dc162501747e1572954704; accessed February 18, 2021). Iodine and As concentrations of feeds and orts were analyzed by inductively coupled plasma mass spectrometry at the Dartmouth College Trace Element Laboratory. Orts were also analyzed for DM, ash, total N, NDF, and ADF at Dairy One Forage Testing Laboratory. Extraction of PT in samples of ASCO meal was performed as described by Wang et al. (2008), with PT analyzed colorimetrically (Genesys 10S
VIS; Thermo Fisher Scientific) at $510 \mathrm{~nm}$ wavelength using the 2,4-dimethoxybenzaldehyde assay (Stern et al., 1996) and phloroglucinol (Acros Organics; Thermo Fisher Scientific) as the analytical standard.

\section{Ruminal Sampling and Analyses}

Ruminal Digesta Collection. Ruminal digesta was collected across the ventral sac approximately $3 \mathrm{~h}$ after the morning feeding during 3 consecutive days (d 23 to 25 of each sampling period) and strained through 2 layers of cheesecloth into volumetric flasks to a final volume of $400 \mathrm{~mL}$. After filtration, samples were pooled per cow by placing $0.6 \mathrm{~mL}$ of ruminal fluid from each day into 2 -mL cryovials $(1.8 \mathrm{~mL}$ total $)$ and stored at $-80^{\circ} \mathrm{C}$ until DNA extraction and sequencing analyses and total bacterial quantification via quantitative (q) PCR. Ruminal fluid samples from each day were also diluted (1:1 ratio) with formalin $(20 \% \mathrm{wt} / \mathrm{vol}$ formaldehyde), pooled by cow, and stored in $50-\mathrm{mL}$ centrifuge tubes at room temperature for protozoal counting.

Ruminal digesta was collected and filtered as described above at 0 (immediately before feeding), 1, 2, 4,6 , and $8 \mathrm{~h}$ after feeding on d 27 of each sampling period, with $\mathrm{pH}$ immediately determined using a $\mathrm{pH}$ meter (sure-flow pH electrode Orion Star A214 m; Thermo Fischer Scientific). Next, $0.8 \mathrm{~mL}$ of $50 \% \mathrm{H}_{2} \mathrm{SO}_{4}$ (vol/vol) was added into $40 \mathrm{~mL}$ of strained ruminal fluid and stored at $-20^{\circ} \mathrm{C}$ for later inhouse analysis of $\mathrm{NH}_{3}-\mathrm{N}$ concentration with an ion-selective electrode (Orion Star A214 m; Thermo Fisher Scientific). Quantification of VFA was done using a GC equipped with a flame ionization detector (model 3300; Varian Inc.) and a $2 \mathrm{~m} \times 2 \mathrm{~mm}$ glass column packed with $10 \%$ stationary phase $1200 / 1 \mathrm{H}_{3} \mathrm{PO}_{4}$ on $80 / 100$ Chromosorb W-AW medium (Supelco Inc.) at the West Virginia University Rumen Fermentation Profiling Laboratory (Morgantown).

Protozoal Count. Total protozoal number was determined as described by Dehority (2005). Briefly, protozoal cells were stained overnight by adding 2 drops of brilliant green dye (Sigma-Aldrich Corp.) into $1 \mathrm{~mL}$ of formalin-preserved sample. Next, $9 \mathrm{~mL}$ of $30 \%$ glycerol solution (vol/vol) was added to the mixture and $1 \mathrm{~mL}$ of the diluted sample was pipetted into a Sedgewick-Rafter counting chamber (Structure Probe Inc.) with $1 \mathrm{~cm}^{3}$ volume. Samples were diluted to bring total protozoal cells to a range of 100 to 200 counts per 50 grids. Protozoal cells were counted in duplicate at $100 \times$ magnification (Olympus HB2). Total protozoa were expressed as cells per milliliter of undiluted ruminal fluid.

Total DNA Extraction from Ruminal Fluid and Bacterial Quantification. Ruminal fluid 
samples were shipped packed on dry ice to MR DNA Laboratory (Shallowater, TX) for DNA extraction, total bacterial quantification, and MiSeq sequencing. Microbial DNA was extracted from ruminal fluid samples using the PowerSoil DNA isolation method (kit \#12888-100; MO BIO Laboratories Inc.) following the manufacturer's guidelines. The DNA was eluted in 100 $\mu \mathrm{L}$ of $\mathrm{C} 6$ solution and quantified using a NanoDrop spectrophotometer (2000 UV-VIS; Thermo Fischer Scientific). Bacterial qPCR analysis was done with a StepOnePlus Real-Time PCR System (Applied Biosystems) using Bacteria2F and Bacteria2R pair of primers (MR DNA Laboratory). Amplifications were done with $1 \mu \mathrm{L}$ of extracted DNA and the TaqMan $2 \times$ Universal PCR Mastermix (Applied Biosystems) under the following conditions: $50^{\circ} \mathrm{C}$ for $2 \mathrm{~min}$ followed by $95^{\circ} \mathrm{C}$ for $10 \mathrm{~min}$ as an initial holding stage, and then 40 cycles of $95^{\circ} \mathrm{C}$ for $15 \mathrm{~s}$ followed by $60^{\circ} \mathrm{C}$ for $1 \mathrm{~min}$. Three replications were performed for each sample, standard, and negative control. Bacterial 16S rRNA gene copies per microliter of ruminal fluid were estimated by comparing the sample cycle threshold against a standard curve constructed using a 10-fold serial dilution of plasmid DNA containing the $16 \mathrm{~S}$ rRNA genes sequence from Escherichia coli.

PCR Amplification and MiSeq Sequencing. Amplification of the $\mathrm{V} 4$ variable region of the bacterial $16 \mathrm{~S}$ rRNA genes was carried out with the primers $515 \mathrm{~F}$ (5'-GTGCCAGCMGCCGCGGTAA-3') and 806R (5'-GGACTACHVGGGTWTCTAAT-3') (Caporaso et al., 2011). The PCR amplifications were performed using the HotStarTaq Plus Master Mix DNA polymerase kit (Qiagen) under the following conditions: $94^{\circ} \mathrm{C}$ for 3 min, followed by 28 cycles of $94^{\circ} \mathrm{C}$ for $30 \mathrm{~s}, 53^{\circ} \mathrm{C}$ for $40 \mathrm{~s}$, and $72^{\circ} \mathrm{C}$ for $1 \mathrm{~min}$. After each cycle, a final elongation step at $72^{\circ} \mathrm{C}$ for 5 min was performed. All PCR products were checked in $2 \%$ agarose gel to determine the success of amplification. Multiple samples were pooled together in equal proportions based on their molecular weight and DNA concentrations and purified using calibrated Ampure XP beads (Beckman Coulter). Purified PCR products were used to prepare sequencing library following the Illumina TruSeq (Illumina Inc.) protocol. Sequencing was performed on a MiSeq (Illumina Inc.) following the manufacturer's guidelines.

Bacterial Diversity and Operational Taxonomic Unit Assignment. The 250-bp paired-end raw Illumina reads from ruminal fluid bacteria were initially evaluated using FastQC (v.0.11.4; Babraham Institute). The reads were then processed to remove Illumina adapters and trimmed to remove low-quality reads (Phred $\leq 30$ ) using Trimmomatic v.0.33 (Bolger et al., 2014). The high-quality paired-end reads were merged using the PEAR software (Zhang et al.,
2014). All postprocessed reads were submitted to the QIIME2 package for microbiota genetic quantitative analysis (Bolyen et al., 2019). Amplicon errors from the high-quality reads were initially corrected with using DADA2 (Callahan et al., 2016) followed by the QIIME2 "demux" function to remove chimeras and duplicated sequences, and to demultiplex the reads according to representative sequences. The taxonomic classification for bacterial $16 \mathrm{~S}$ rRNA genes was performed through a pre-fitted sklearn-based taxonomy classifier (Pedregosa et al., 2011) using SILVA (v.132; Quast et al., 2013) and Greengenes (DeSantis et al., 2006) both with a similarity threshold of $99 \%$. It should be noted that $93 \%$ of the assignments were done via SILVA and only $7 \%$ through Greengenes, which complemented SILVA by classifying additional 5 genera. Biodiversity differences of ruminal fluid bacteria in response to treatments were compared by the $\alpha$ diversity indices Shannon (Shannon and Weaver, 1949), Simpson (Simpson, 1949), and Fisher (Fisher et al., 1943).

\section{Blood Sampling and Analyses}

Blood was collected via the coccygeal vessels on $d$ 27 and 28 of each sampling period approximately 4 $\mathrm{h}$ after the morning feeding. Two 10-mL Vacutainer tubes (Monoject Covidien) were used, with the first containing EDTA for plasma harvesting and the second without anticoagulant for serum. After collection, tubes were immediately placed on ice and centrifuged (Eppendorf Centrifuge model 5810) at 2,155 $\times g$ for $20 \mathrm{~min}$ at $4^{\circ} \mathrm{C}$. Plasma and serum samples were pooled and aliquots stored in cryovials at $-80^{\circ} \mathrm{C}$ until analyses.

Serum samples were analyzed for cortisol (Immulite 1000; Siemens Inc.), thyroid hormones [total triiodothyronine $\left(\mathbf{T}_{3}\right)$ and total thyroxin $\left(\mathbf{T}_{4}\right)$; Immulite 2000; Siemens Inc.], insulin (kit \#PI-12K; Millipore Corp.), and fatty acids (NEFA-HR kit; Wako Diagnostics, Beckman Coulter) at the Cornell University Animal Health Diagnostic Center (Ithaca, NY). Plasma concentrations of glucose (Gluco-quant Glucose/HK; Roche Diagnostics), BHBA (Randox kit \#RB1007), and urea N (kinetic UV assay; Roche Diagnostics) were also analyzed at the Cornell University Animal Health Diagnostic Center. Plasma samples were further analyzed inhouse for glutathione peroxidase, superoxidase dismutase, and catalase activities (kits \#703102, \#706002, and \#707002, respectively; Cayman Chemical Co.) using a microplate reader (Biotek Synergy HT; Biotek Instruments Inc.). Serum concentrations of aldosterone (kit \#501090; Cayman Chemical Co.) and thyroid-stimulating hormone (TSH; kit \#BT0029, NEO Scientific) were analyzed inhouse following manufacturers' protocols. Samples of serum were shipped 
to Dartmouth College Trace Element Laboratory and analyzed for I and As concentrations by inductively coupled plasma mass spectrometry.

\section{Urinary and Fecal Sampling and Analyses}

Spot urinary samples were collected for 3 consecutive days during each sampling period by stimulation of the pudendal nerve massaging the area below the vulva at $0600 \mathrm{~h}$ (d 22), $1200 \mathrm{~h}$ (d 23), and $1800 \mathrm{~h}$ (d 24). Samples were acidified (1:5 ratio) with $0.072 \mathrm{~N} \mathrm{H}_{2} \mathrm{SO}_{4}$, pooled by cow over the $3 \mathrm{~d}$, and stored at $-20^{\circ} \mathrm{C}$. Nonacidified aliquots of urine from each time point were pooled into $50-\mathrm{mL}$ centrifuge tubes and kept at $-20^{\circ} \mathrm{C}$ for I and As analyses by inductively coupled plasma mass spectrometry (Dartmouth College Trace Element Laboratory). Urinary concentrations of allantoin (Chen et al., 1992) and uric acid (Stanbio kit \#1045) were conducted inhouse using a DU 520 spectrophotometer (Beckman Coulter). Creatinine (kit \#500701, Cayman Chemical Co.) concentration in urine was also analyzed inhouse colorimetrically with a microplate reader (Chromate model 4300; Awareness Technology Inc.). Total urinary $\mathrm{N}$ was done using the micro-Kjeldahl method at Dairy One Forage Testing Laboratory, with urinary volume estimated assuming a constant creatinine excretion of $0.212 \mathrm{mmol} / \mathrm{kg}$ of BW (Chizzotti et al., 2008).

Fecal grab samples were collected directly from the rectum or during voluntary defecation concurrently with urinary sampling. Fecal samples were placed in disposable aluminum foil pans and dried in a forced-air oven at $55^{\circ} \mathrm{C}$ (VWR Scientific) for approximately $96 \mathrm{~h}$. Samples from each time point were individually ground to pass through a $1-\mathrm{mm}$ screen Wiley mill, pooled by cow, and analyzed for DM, ash, total N, NDF, and ADF by Dairy One Forage Testing Laboratory. Feeds, orts, and fecal samples were weighed $(\sim 0.5 \mathrm{~g})$ into filter bags (F57; Ankom Technology), placed in a larger nylon bag $(30 \times 45 \mathrm{~cm})$, and incubated into the rumen of 1 ruminally cannulated Jersey cow (220 DIM; $17 \mathrm{~kg}$ of milk yield) for $12 \mathrm{~d}$. A mixed grass-legume haylage/ corn silage-based TMR with a 68:32 forage:concentrate ratio (DM basis; $16.8 \% \mathrm{CP}$ and $33.2 \% \mathrm{NDF}$ ) was fed to the ruminally cannulated cow. After removal from the rumen, bags were rinsed, dried overnight in a forced-air oven at $55^{\circ} \mathrm{C}$ (VWR Scientific), and analyzed inhouse for $\mathrm{ADF}$ using an Ankom ${ }^{2000}$ fiber analyzer (Ankom Technology). Indigestible ADF was used as an internal marker to estimate fecal output of DM and apparent total-tract digestibility of nutrients (Cochran et al., 1986; Huhtanen et al., 1994). Fecal and urinary I and As concentrations were determined as reported previously.

\section{Milk Sampling and Analyses}

Cows were milked twice daily $(0530 \mathrm{~h}$ and $1730 \mathrm{~h})$ with milk yield recorded every milking throughout the experiment. Milk samples were collected during 4 consecutive milkings beginning in the afternoon of $\mathrm{d}$ 22 and completed in the morning of d 24 of each sampling period. Samples were placed into tubes containing 2-bromo-2-nitropropane-1,3 diol, pooled by cow according to afternoon and morning milk weights, and kept refrigerated at $4^{\circ} \mathrm{C}$ until shipped to Dairy One DHIA for analyses of fat, true protein, lactose, and MUN by mid-infrared spectroscopy in a Milkoscan (Foss Inc.), and SCC by flow cytometry in a Fossomatic (Foss Inc.). Milk samples for I and As analyses were collected in 50-mL centrifuge tubes without preservative on d 22 (afternoon milking) and d 23 (morning milking) of each sampling period. These samples were pooled and kept at $-20^{\circ} \mathrm{C}$ until I and As analyses as reported earlier.

\section{Statistical Analyses}

Data were checked for normality by the Shapiro-Wilk test using the PROC UNIVARIATE of SAS (version 9.4; SAS Institute Inc.) and, when necessary, $\log _{10^{-}}$ transformed (i.e., bacterial 16S rRNA gene copies, relative abundance of bacterial taxa) before further analysis. Analysis of variance was performed using the PROC MIXED procedures of SAS (version 9.4; SAS Institute Inc.). The following model was used for all variables without repeated measures over time:

$$
\mathrm{Y}_{\mathrm{ijk}}=\mu+\mathrm{C}_{\mathrm{i}}+\mathrm{P}_{\mathrm{j}}+\mathrm{T}_{\mathrm{k}}+\varepsilon_{\mathrm{ijk}}
$$

where $Y_{i j k}=$ dependent variable, $\mu=$ overall mean, $C_{i}$ $=$ random effect of the ith cow, $P_{j}=$ fixed effect of the jth period, $\mathrm{T}_{\mathrm{k}}=$ fixed effect of the kth treatment, and $\varepsilon_{\mathrm{ijk}}=$ residual error.

The following model was used for variables with repeated measures over time (i.e., ruminal $\mathrm{pH}, \mathrm{VFA}$, and $\left.\mathrm{NH}_{3}-\mathrm{N}\right)$ :

$$
\begin{aligned}
\mathrm{Y}_{\mathrm{ijkl}}=\mu & +\mathrm{C}_{\mathrm{i}}+\mathrm{P}_{\mathrm{j}}+\mathrm{T}_{\mathrm{k}}+\varepsilon 1_{\mathrm{ijk}}+\mathrm{H}_{\mathrm{l}} \\
& +\mathrm{T} \times \mathrm{H}_{\mathrm{kl}}+\varepsilon 2_{\mathrm{ijk}},
\end{aligned}
$$

where $\mathrm{Y}_{\mathrm{ijkl}}=$ dependent variable, $\mu=$ overall mean, $\mathrm{C}_{\mathrm{i}}$ $=$ random effect of the ith cow, $\mathrm{P}_{\mathrm{j}}=$ fixed effect of the jth period, $T_{k}=$ fixed effect of the kth treatment, $\varepsilon 1_{\mathrm{ijk}}$ = plot residual error, $\mathrm{H}_{1}=$ fixed effect of lth sampling time denoted as hours before and after feeding, $\mathrm{T} \times \mathrm{H}_{\mathrm{kl}}$ $=$ interaction between the $\mathrm{kth}$ treatment and the lth sampling time, and $\varepsilon 2_{\mathrm{ijkl}}=$ subplot residual error. Six 
covariance structures were tested (spatial power, autoregressive, compound symmetry, unstructured, Toeplitz, and variance component) and the one yielding the lowest Bayesian information criterion for each variable was kept in the final model. Cow nested within period was used as the subject of the repeated statement in SAS. Preplanned, nonorthogonal contrasts were used for all variables to compare treatment effects using ANOVA. Degrees of freedom for treatments were partitioned as follows: (1) linear and quadratic effects of ASCO meal supplementation $(0,57,113$, and $170 \mathrm{~g} / \mathrm{d}),(2) \mathrm{MON}$ versus ASCO meal supplementation (57, 113, and 170 $\mathrm{g} / \mathrm{d}$ ), and (3) MON supplementation versus the control diet $(0 \mathrm{~g} / \mathrm{d}$ of ASCO meal). Significance was declared at $P \leq 0.05$ and trends at $0.05<P \leq 0.10$.

\section{RESULTS AND DISCUSSION}

\section{ASCO Meal Chemical Composition}

The ingredient and chemical composition of the basal diet, and the chemical composition of ASCO meal are presented in Table 1. The chemical composition of all remaining ingredients used in the basal diet is presented in Supplemental Table S1 (https://figshare .com/articles/dataset/Supplemental_Table_S1_docx/ 19140212; Brito, 2022a). Iodine concentration of ASCO meal averaged $415 \mathrm{mg} / \mathrm{kg}$ of DM (Table 1), and it was $46 \%$ lower than that reported in our previous research $($ mean $=774 \mathrm{mg} / \mathrm{kg}$ of DM; Antaya et al., 2015, 2019). Evans and Critchley (2014) showed that the I concentration of ASCO meal made from the 2002-2006 wild harvests across the eastern shores of Atlantic Canada ranged from 600 to $1,000 \mathrm{mg} / \mathrm{kg}$ (typical I concentration $=700 \mathrm{mg} / \mathrm{kg}$ ). Therefore, the atypical I concentration of the ASCO meal fed herein compared with the literature may be associated with annual or seasonal variation, as well as differences in processing methods, supply source, and analytical protocols.

The concentration of As in ASCO meal averaged $14.9 \mathrm{mg} / \mathrm{kg}$ of DM (Table 1), and it was, on average, $53 \%$ lower than the mean values of 28.3 and $35.7 \mathrm{mg}$ of As $/ \mathrm{kg}$ of DM reported by Sorge et al. (2016b) and Monagail et al. (2018), respectively. However, our As concentration was close to the lower limit range of As (15.3 to $29.8 \mathrm{mg} / \mathrm{kg}$ of air-dried sample) found in ASCO harvested from the New England cost of the United States (Taylor and Jackson, 2016). Among macroalgae species, brown seaweeds accumulate more As (Taylor and Jackson, 2016), which is known to be a potentially toxic metalloid (Biancarosa et al., 2018). Nevertheless, compared with other brown seaweeds including Laminaria digitata, ASCO has been shown to have lower As concentration (Taylor and Jackson, 2016).
Brown seaweeds can also produce and accumulate PT, an oligomer of phloroglucinol with antimicrobial and antiherbivory properties (Svensson et al., 2007; Wang et al., 2009b). The ASCO meal used herein averaged $8.71 \mathrm{~g}$ of PT $/ \mathrm{kg}$ of DM (Table 1), and thus $257 \%$ greater than that (i.e., $2.44 \mathrm{~g}$ of $\mathrm{PT} / \mathrm{kg}$ of $\mathrm{DM}$ ) reported by Belanche et al. (2016a). It is well known that the concentration of $\mathrm{PT}$ in ASCO tissues varies in response to season (Connan et al., 2004), herbivory (Toth et al., 2005; Svensson et al., 2007), tide depth (Connan et al., 2004), and nutrient availability (Svensson et al., 2007), indicating that PT levels in ASCO meal are expected to differ across sources.

\section{Ruminal Fermentation Profile}

Ruminal $\mathrm{pH}$ did not change significantly and averaged 6.02 across diets (Table 2). We are not aware of

Table 1. Ingredient and chemical composition of the basal diet fed as TMR, and chemical composition of the brown seaweed Ascophyllum nodosum (ASCO) meal

\begin{tabular}{|c|c|c|}
\hline Item & $\begin{array}{c}\text { Basal } \\
\text { diet }\end{array}$ & $\begin{array}{c}\text { ASCO } \\
\text { meal }\end{array}$ \\
\hline \multicolumn{3}{|l|}{ Ingredient, $\%$ of diet DM } \\
\hline Corn silage & 25.5 & - \\
\hline Grass-legume silage & 40.8 & - \\
\hline Ground corn & 20.9 & - \\
\hline Soybean meal & 7.50 & - \\
\hline Roasted soybean & 3.52 & - \\
\hline Mineral-vitamin premix ${ }^{1}$ & 1.83 & - \\
\hline \multicolumn{3}{|c|}{ Nutrient composition, \% of DM unless otherwise noted } \\
\hline DM, $\%$ of fresh matter & 50.7 & 88.9 \\
\hline $\mathrm{CP}$ & 15.8 & 7.65 \\
\hline Soluble CP, \% of CP & 43.5 & 39.5 \\
\hline Neutral detergent insoluble CP & 3.38 & 5.40 \\
\hline Acid detergent insoluble $\mathrm{CP}$ & 1.56 & 4.75 \\
\hline Ash-free NDF & 37.3 & 46.8 \\
\hline $\mathrm{ADF}$ & 24.7 & 31.9 \\
\hline ADL & 3.97 & 16.3 \\
\hline Starch & 22.9 & 0.70 \\
\hline Ethanol-soluble carbohydrates & 2.95 & 0.95 \\
\hline Ether extract & 4.37 & 3.40 \\
\hline $\mathrm{NE}_{\mathrm{L}}, \mathrm{Mcal} / \mathrm{kg}$ of $\mathrm{DM}$ & 1.60 & 0.81 \\
\hline Phlorotannins, $\mathrm{g} / \mathrm{kg}$ of $\mathrm{DM}$ & $\mathrm{NA}^{2}$ & 8.71 \\
\hline $\mathrm{Ca}$ & 0.61 & 1.12 \\
\hline $\mathrm{P}$ & 0.36 & 0.16 \\
\hline $\mathrm{Mg}$ & 0.31 & 0.89 \\
\hline $\mathrm{K}$ & 1.58 & 2.51 \\
\hline $\mathrm{Na}$ & 0.29 & 3.42 \\
\hline $\mathrm{S}$ & 0.20 & 3.37 \\
\hline $\mathrm{I}, \mathrm{mg} / \mathrm{kg}$ & 0.38 & 415 \\
\hline As, $\mathrm{mg} / \mathrm{kg}$ & 0.08 & 14.9 \\
\hline $\mathrm{Fe}, \mathrm{mg} / \mathrm{kg}$ & 182 & 234 \\
\hline $\mathrm{Zn}, \mathrm{mg} / \mathrm{kg}$ & 25.3 & 33.5 \\
\hline $\mathrm{Cu}, \mathrm{mg} / \mathrm{kg}$ & 7.08 & 2.50 \\
\hline $\mathrm{Mn}, \mathrm{mg} / \mathrm{kg}$ & 32.0 & 24.5 \\
\hline Mo, mg $/ \mathrm{kg}$ & 2.53 & 1.15 \\
\hline
\end{tabular}

${ }^{1}$ Premix composition (DM basis): Ca (13.12\%), P (1.76\%), $\mathrm{Mg}$ (6.22\%), K (0.04\%), S (0.30\%), Na (13.9\%), Cl (9.05\%), Se (9.03 mg/ $\mathrm{kg})$, As $(0.86 \mathrm{mg} / \mathrm{kg})$, I $(14.3 \mathrm{mg} / \mathrm{kg})$, and vitamin A $(39,508 \mathrm{IU} / \mathrm{kg})$. ${ }^{2} \mathrm{NA}=$ not analyzed. 
any published study that has investigated the effect of ASCO meal supplementation on ruminal fermentation profile in lactating dairy cows. Therefore, we compared our results against those obtained during in vitro or in vivo experiments done with sheep and steers. Belanche et al. (2016b) reported linear and quadratic decreases in ruminal $\mathrm{pH}$ in batch culture vials incubated with incremental amounts of ASCO meal. In contrast, Belanche et al. (2016a) observed no differences in ruminal $\mathrm{pH}$ between the control diet and that supplemented with $5 \%$ of lyophilized ASCO meal during continuous culture using the rumen simulation technique (i.e., RUSITEC). Likewise, ruminal $\mathrm{pH}$ was not affected in Holstein steers fed a cooked molasses block containing $10 \mathrm{~g}$ of ASCO meal $(0.12 \%$ of the diet DM; Leupp et al., 2005), as well as in lambs supplemented with ASCO meal at $1 \%$ (Fike et al., 2005) or up to $5 \%$ of the diet DM (Zhou et al., 2018). We did not observe treatment effects on ruminal $\mathrm{NH}_{3}-\mathrm{N}$ concentration, which averaged $6.83 \mathrm{mg} / \mathrm{dL}$ across diets (Table 2) and agrees with previous in vitro (Belanche et al., 2016a,b) and in vivo (Leupp et al., 2005; Zhou et al., 2018) studies.

The ruminal concentration of total VFA decreased linearly $(P=0.02)$ in cows fed incremental amounts of ASCO meal (Table 2), with this response being independent of total protozoal and bacterial numbers (Table 3), as well as DMI (Table 4), which did not differ significantly across treatments. Previous research showed no changes in ruminal total VFA concentration with feeding various amounts of ASCO meal in vitro (Belanche et al., 2016a,b) or in vivo to Holstein steers (Leupp et al., 2005) or hams (Zhou et al., 2018). This discrepancy in total VFA concentration between our results and those from the literature is difficult to explain because the proportion of ASCO meal included herein (i.e., $0.24,0.54$, and $0.81 \%$ of DMI) was lower than levels (up to $5 \%$ of the diet DM) used by Belanche et al. (2016a,b) and Zhou et al. (2018), but greater in comparison to Leupp et al. (2005; i.e., $0.12 \%$ of the diet $\mathrm{DM})$. Therefore, differences in the concentrations of PT among different sources of ASCO meal, animal species used (i.e., lactating dairy cows, hams, steers), and type of experiment (in vitro vs. in vivo) may be involved in the discrepant ruminal VFA concentration in response to ASCO.

Feeding incremental amounts ASCO meal did not affect the ruminal molar proportions of individual VFA except for butyrate, which responded quadratically $(P$ $<0.001)$ with the lowest values seen in diets supplemented with 57 or $113 \mathrm{~g} / \mathrm{d}$ of ASCO meal (Table 2). Dietary inclusion of ASCO either as an extract applied to endophyte-infested tall fescue herbage harvested as hay or via direct supplementation of an ASCO extract (1\%, DM basis) reduced the ruminal concentration of butyrate in lambs by $10 \%$ compared with the control diet (Fike et al., 2005). Zhou et al. (2018) reported linear and quadratic decreases in the ruminal molar proportion of butyrate in rams supplemented with increasing levels of ASCO meal (0 to $5 \%$ of the diet DM). Overall, our data and previous results (Fike et al., 2005; Zhou et al., 2018) showed that ASCO decreased the ruminal molar proportion or concentration of butyrate, but the mechanism behind this response is unclear.

Cows fed the MON diet showed greater $(P \leq 0.03)$ ruminal molar proportion of propionate compared with those fed the control diet or different levels of ASCO meal (Table 2). Whereas the ruminal molar proportion of butyrate decreased $(P=0.02)$ with feeding MON

Table 2. Ruminal fermentation profile in Jersey cows supplemented with incremental amounts of Ascophyllum nodosum (ASCO) meal or monensin $(\mathrm{MON})^{1}$

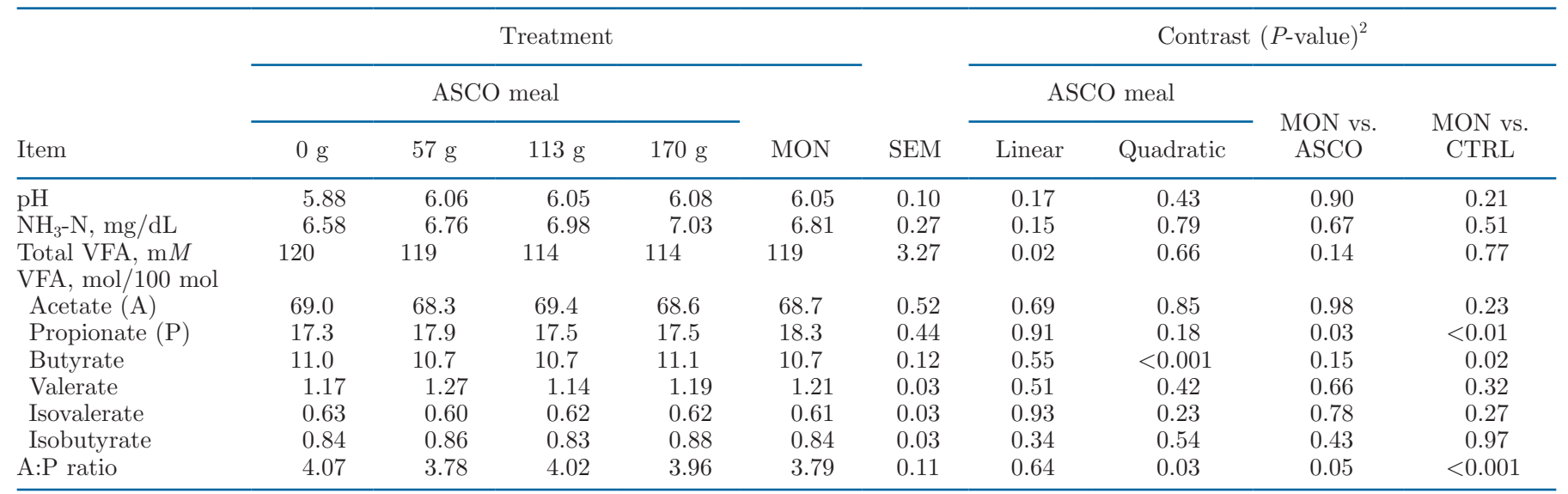

${ }^{1}$ Supplied as a medicated pellet feed (113 g/d; Poulin Grain Inc.) to deliver $300 \mathrm{mg} / \mathrm{d}$ of monensin sodium.

${ }^{2}$ Nonorthogonal contrasts were used to compare: (1) linear and quadratic effects in response to incremental amounts of ASCO meal supplementation; (2) MON versus ASCO meal treatments (57, 113, and $170 \mathrm{~g} / \mathrm{d}$ ); and (3) MON versus the control diet (CTRL, $0 \mathrm{~g} / \mathrm{d}$ of ASCO meal). 
Table 3. Ruminal microbiota population numbers and $\alpha$ diversity indices in Jersey cows supplemented with incremental amounts of Ascophyllum nodosum (ASCO) meal or monensin $(\mathrm{MON})^{1}$

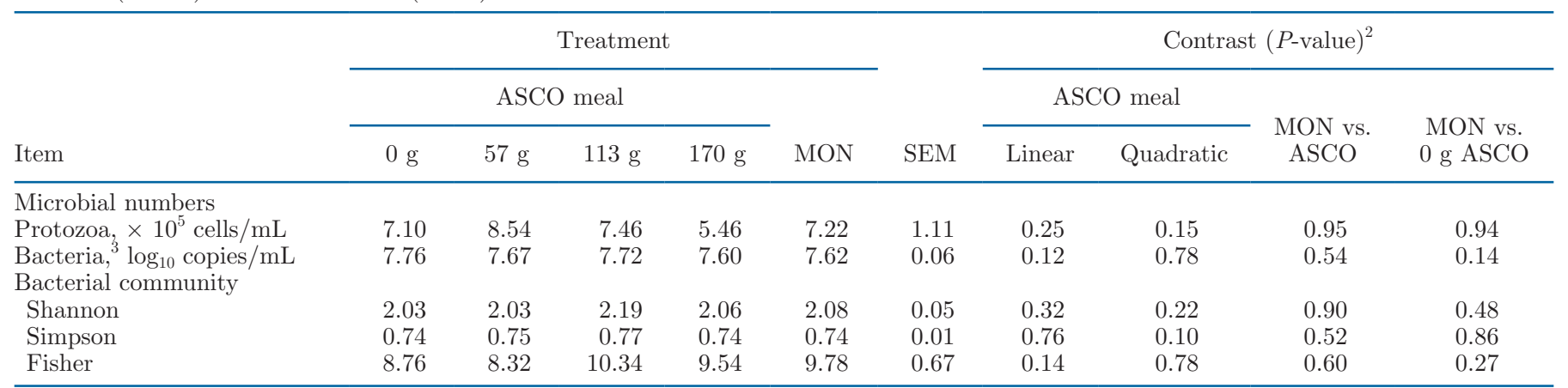

${ }^{1}$ Supplied as a medicated pellet feed $(113 \mathrm{~g} / \mathrm{d}$; Poulin Grain Inc.) to deliver $300 \mathrm{mg} / \mathrm{d}$ of monensin sodium.

${ }^{2}$ Nonorthogonal contrasts were used to compare: (1) linear and quadratic effects in response to incremental amounts of ASCO meal supplementation; (2) MON versus ASCO meal treatments (57, 113, and $170 \mathrm{~g} / \mathrm{d}$ ); and (3) MON versus the control diet (0 g/d of ASCO meal).

${ }^{3}$ Bacterial 16S rRNA genes.

versus the control diet, no change $(P=0.15)$ was observed in cows offered MON versus ASCO meal (Table 2 ). Likewise, MON supplementation had no effect on the ruminal molar proportions of acetate, valerate, iso- valerate, and isobutyrate (Table 2). Increased ruminal propionate with similar acetate reduced $(P \leq 0.05)$ the acetate-to-propionate ratio in cows receiving MON. It is well known that MON selectively inhibit gram-positive

Table 4. Apparent total-tract digestibilities of nutrients, and intake, output, and serum concentrations of iodine and arsenic in Jersey cows supplemented with incremental amounts of Ascophyllum nodosum (ASCO) meal or monensin (MON) ${ }^{1}$

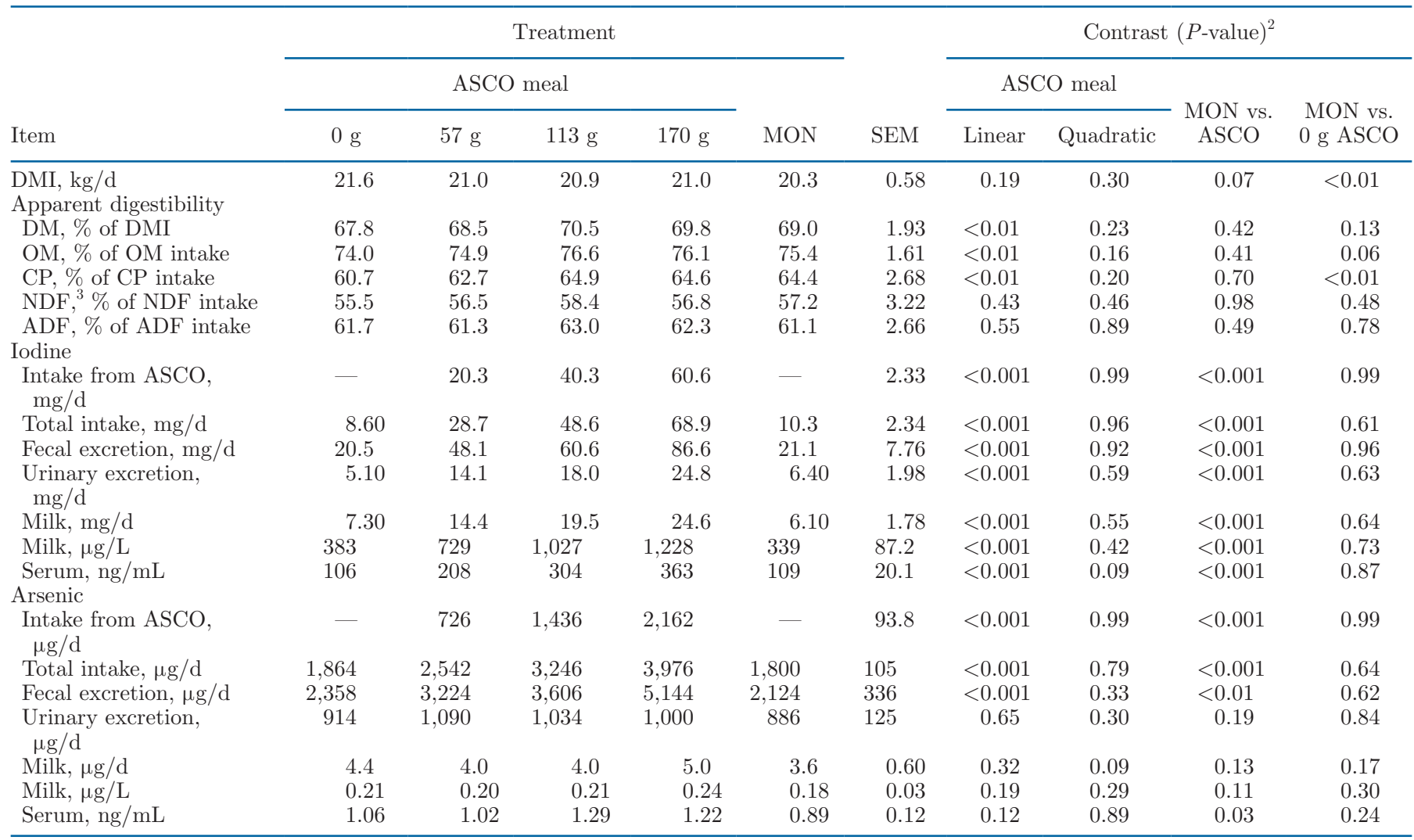

${ }^{1}$ Supplied as a medicated pellet feed (113 g/d; Poulin Grain Inc.) to deliver $300 \mathrm{mg} / \mathrm{d}$ of monensin sodium.

${ }^{2}$ Nonorthogonal contrasts were used to compare: (1) linear and quadratic effects in response to incremental amounts of ASCO meal supplementation; (2) MON versus ASCO meal treatments (57, 113, and $170 \mathrm{~g} / \mathrm{d}$ ); and (3) MON versus the control diet (0 g/d of ASCO meal).

${ }^{3}$ Dietary ingredients were analyzed for ash-free NDF, and orts and fecal samples for NDF. 
bacteria in the rumen, leading to increased propionate in lactating dairy cows (Broderick, 2004; Duffield et al., 2008a).

\section{Total Protozoal and Bacterial Population Numbers}

No treatment effect was observed for total protozoa (via microscopy) numbers and bacterial 16S rRNA gene copies (via qPCR) in ruminal fluid samples, which averaged $7.17 \times 10^{5}$ cells $/ \mathrm{mL}$ and $7.67 \log _{10}$ copies $/ \mathrm{mL}$ across diets, respectively (Table 3 ). In contrast, Zhou et al. (2018) reported linear and quadratic decreases in the total number of ruminal bacteria (via $\mathrm{qPCR}$ ) and a linear increase in that of protozoa (cells $/ \mathrm{mL}$ of ruminal fluid; quantification method not reported) in rams fed incremental amounts of ASCO meal. Belanche et al. (2016a) demonstrated a 77\% reduction in total protozoal count (qPCR) when $5 \%$ of ASCO meal (\% of diet DM) was dosed during continuous culture compared with the control diet. These discrepancies across studies may be associated with differences in the dietary proportion of ASCO meal used, ASCO meal form and processing method (ground and air-dried vs. lyophilized and powdered), experimental type (in vivo vs. in vitro), and quantification method (qPCR vs. microscopy). The lack of MON effect on total protozoal numbers agrees with previous research in which MON was fed to lactating dairy cows (Reveneau et al., 2012; Schären et al., 2017).

As stated above, bacterial 16S rRNA genes averaged $7.67 \log _{10}$ copies $/ \mathrm{mL}$ and was lower than that reported in previous research (e.g., Zhou et al., 2018), which may be associated with ruminal sample type (i.e., fluid vs. whole ruminal) or sampling time or both. Lengowski et al. (2016) reported that total bacteria gene copy number in the fluid fraction of the rumen was lower than that in the solid fraction in dairy cows fed either corn silage- or grass silage-based diets. In addition, Lengowski et al. (2016) found that sampling time affected total bacterial gene copy numbers in the fluid but not in the solid phase, showing that the concentration of fluid-associated bacteria appears to be more variable. Mullins et al. (2013) observed that the proportion (\% of total bacteria) of solid-associated bacteria measured via $\mathrm{qPCR}$ was about 4 times greater relative to that of the fluid fraction.

\section{Diversity and Relative Abundance of Ruminal Bacterial Taxa}

We used a Latin square design to assess the effect of incremental amounts of ASCO meal and MON on diversity and relative abundance of ruminal bacterial taxa. One of the concerns when using changeover designs is the potential carryover effect of a given treatment on the variables of interest during the next period. However, we used 28-d periods with $21 \mathrm{~d}$ for diet adaptation and $7 \mathrm{~d}$ for data and sample collection (ruminal fluid obtained between d 23 to 25 of each period), which is possibly enough time for both cows and the ruminal microbiota to adapt after switching to a new diet. According to Machado et al. (2016), the composition of the ruminal fluid-associated bacteria community stabilized between 3 to $9 \mathrm{~d}$ (mean $=7.2 \mathrm{~d}$ ), following a dietary change in ruminally cannulated crossbreed cattle. In contrast, ruminal microbiota stability did not happen until about 9 wk after a transition from a high forage to a high concentrate diet in an experiment done with growing Angus steers (Clemmons et al., 2019). It should be also noted that due to our ruminal digesta filtration procedure the resulting samples mostly represent a microbial community associated with the fluid phase. Ji et al. (2017) concluded that different ruminal fractions (i.e., whole digesta, fluid fraction, and solid fraction) yielded similar bacterial diversity, but the fluid fraction contributed most to the difference in relative abundance of bacterial taxa with feeding the high forage diet to dairy cows. We also did not collect baseline/covariate ruminal digesta samples, which could have helped us to identify whether a shift in relative abundance of ruminal microbiota was caused by an effect of treatment and not individual cow variation. It is important to emphasize that covariate sampling is not typical in Latin square designs because individual variation (i.e., host effect) is accounted for as every treatment is assigned to each animal throughout the study. Overall, our diversity and sequencing data presented below should be interpreted in the context of the limitations and uncertainties of a changeover design and the use of ruminal fluid to represent the bacterial changes in response to treatments.

Bacterial $\alpha$ indices were not significantly affected by diets (Table 3), which agrees with Belanche et al. (2016a) in continuous culture dosed with $5 \%$ of ASCO meal. Feeding incremental amounts of ASCO meal linearly decreased $(P=0.05)$ the relative abundance of the ruminal Tenericutes phylum (Figure 1A), thus in line with results from Zhou et al. (2018). Jiménez et al. (2010) showed that an acetone extract derived from ASCO had stronger antimicrobial activity toward gram-positive than gram-negative bacteria. However, the phylum Tenericutes is composed of gram-negative bacteria (Brown, 2018), and ASCO meal reduced the total population and prevalence of the gram-negative bacterium E. coli in the rumen of rams (Zhou et al., 2018). Therefore, it is unclear whether the antimicrobial activity of ASCO meal is Gram staining specific. It is well known that MON is particularly effective 
A

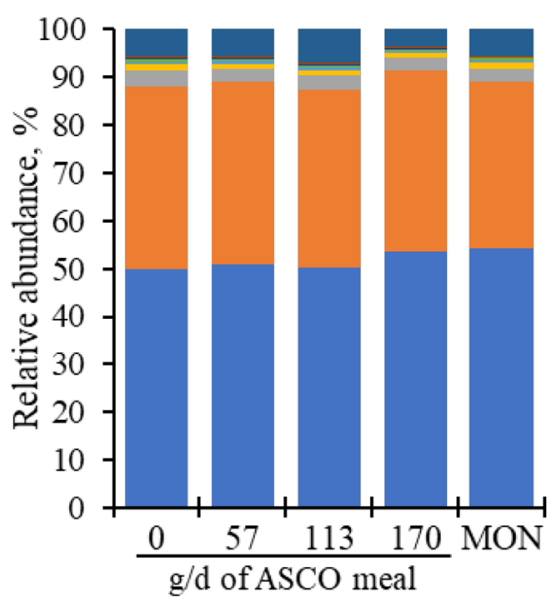

B

n Others

- Synergistetes

- Elusimicrobia

- Planctomycetes

- Fibrobacteres

Patescibacteria

- Proteobacteria

- Tenericutes $*$

- Spirochaetesł

- Bacteroi detes

- Firmicutes
B

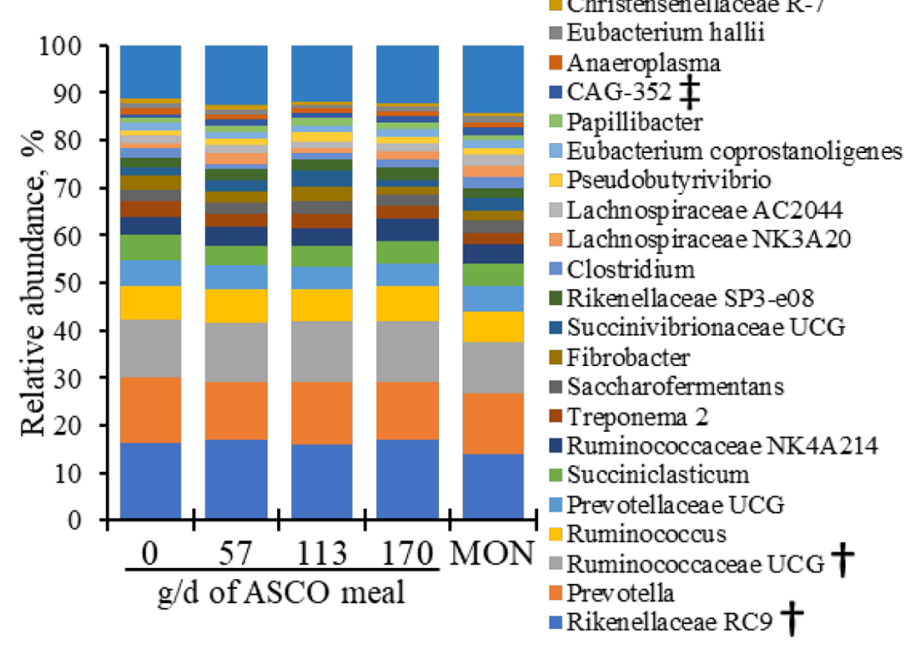

Figure 1. Relative abundance (\%) of ruminal bacterial phyla (A) and bacterial genera (B) in Jersey cows supplemented with incremental amounts of Ascophyllum nodosum (ASCO) meal or $300 \mathrm{mg} / \mathrm{d}$ of monensin [MON; supplied as a medicated pellet feed (113 g/d; Poulin Grain Inc.) to deliver $300 \mathrm{mg} / \mathrm{d}$ of monensin sodium]; * indicates a linear decrease $(P \leq 0.05)$ in response to ASCO meal supplementation; $\dagger$ indicates a difference $(P \leq 0.05)$ between MON and ASCO meal treatments; $\ddagger$ indicates a difference $(P \leq 0.05)$ between MON and the control diet $(0$ $\mathrm{g} / \mathrm{d}$ of ASCO meal). "Others" represents ruminal bacterial taxa below $1 \%$ of relative abundance and unassigned operational taxonomic units.

against gram-positive bacteria (Russell, 1987). In fact, MON did not affect the relative abundance of ruminal Tenericutes compared with ASCO meal or the control diet in the present study. Compared with the control diet, MON supplementation tended $(P=0.07)$ to decrease the relative abundance of the ruminal Spirochaetes phylum (Figure 1A). In contrast, no change in the relative abundance of Spirochaetes was observed when incremental amounts of MON were supplemented to lactating dairy cows (McGarvey et al., 2019).

Supplementation with ASCO meal did not significantly affect the relative abundance of ruminal bacteria genera (Figure 1B). The relative abundance of the uncultured $C A G: 352$ bacterial genus increased $(P$ $=0.02)$ in cows fed MON compared with those fed the control diet (Figure 1B). Even though the $C A G$ : 352 genus is not characterized, it has been shown to be present in the rumen of cattle but not in the rumen of yak (Bos grunniens; Ren et al., 2020). The ruminal relative abundance of Treponema 2 genus tended $(P=0.10$; Figure 1B) to be lower in cows fed MON versus the control diet. Ruminal bacteria belonging to the Treponema genus has been shown to be fibrolytic (Bekele et al., 2011). However, the apparent total-tract digestibilities of NDF and ADF were not affected by MON supplementation (Table 4).

Cows supplemented with MON had lower $(P=0.04)$ relative abundance of the uncultured ruminal bacterial genera Rikenellaceae RC9 and Ruminococcaceae UCG than those fed ASCO meal (Figure 1B). Schären et al. (2017) also reported a decrease in the relative abundance of all 8 operational taxonomic units identified as the Rikenellaceae RC9 gut group in cows receiving $335 \mathrm{mg} / \mathrm{d}$ of MON compared with the control diet. In addition, Schären et al. (2017) observed that the relative abundance of ruminal bacteria $(\mathrm{n}=3$ operational taxonomic units) belonging to the family Ruminococcaceae decreased in response to MON supplementation. It is important to note that the metabolism of Rikenellaceae RC9 gut group and Ruminococcaceae UCG is poorly characterized as bacterial species belonging to these genera are unculturable (Schären et al., 2017). Nevertheless, members from the Rikenellaceae and $R u$ minococcaceae families have been categorized as fibrolytic (Liu et al., 2016) and acetate producers (EsquivelElizondo et al., 2017). Thus, it is conceivable that the reduced relative abundance of these 2 genera may have been linked to the shift of ruminal fermentation from acetate to propionate in cows fed the MON diet (Table 2 ).

\section{Apparent Total-Tract Digestibility of Nutrients}

The apparent total-tract digestibilities of DM, OM, and CP increased linearly $(P<0.01)$ in cows fed incremental amounts of ASCO meal, but no changes were detected for NDF and ADF digestion (Table 4). Therefore, the linear increase in OM digestibility is likely ex- 
plained by the improvement in CP digestibility. Antaya et al. (2015) reported a significant quadratic response for the apparent total-tract digestibility of ADF and quadratic trends for both $\mathrm{OM}$ and NDF digestibilities in dairy cows receiving various levels of ASCO meal. Specifically, OM, NDF, and ADF digestibilities were greatest when ASCO meal was supplemented at 113 g/d and lowest at $176 \mathrm{~g} / \mathrm{d}$. Antaya et al. (2015) also observed that ASCO meal tended to decrease the apparent total-tract digestibility of CP in a linear fashion, which agrees with Zhou et al. (2018). Contrarily, Antaya et al. (2019) reported no effect of ASCO meal supplementation $(113 \mathrm{~g} / \mathrm{d})$ on the apparent total-tract digestibilities of DM, OM, NDF, ADF, and CP in grazing dairy cows. These discrepant results can be explained, at least partially, by differences in the amounts of ASCO meal fed and the concentration of PT in ASCO meal.

Monensin supplementation tended $(P=0.06)$ to increase the apparent total-tract digestibility of $\mathrm{OM}$ and increased $(P<0.01)$ that of $\mathrm{CP}$ compared with the control diet (Table 4). It is well known that MON inhibits the activity of proteolytic and obligate-AA fermenting ruminal bacteria, which may result in less $\mathrm{NH}_{3}$ formation in the rumen and more escape of dietary protein (Yang and Russell, 1993; Ipharraguerre and Clark, 2003). Therefore, improved CP digestibility in cows supplemented with MON may be explained by decreased ruminal proteolysis and increased flow of dietary protein to the small intestine despite no change in the concentration of ruminal $\mathrm{NH}_{3}-\mathrm{N}$ (Table 3). Diets supplemented with ASCO meal or MON did not significantly affect the urinary excretion of total $\mathrm{N}$, urea $\mathrm{N}$, and total purine derivatives (Supplemental Table S2, https://figshare.com/articles/dataset/Supplemental _Table_S2/19140275; Brito, 2022b).

\section{Iodine and Arsenic Metabolism}

Iodine intake increased linearly $(P<0.001$; Table 4$)$ in dairy cows fed incremental amounts of ASCO meal due to the high concentration of I in ASCO tissues as discussed earlier. The I requirement of lactating dairy cows is estimated to be at $1.5 \mathrm{mg}$ of $\mathrm{I} / 100 \mathrm{~kg}$ of $\mathrm{BW}$ (NRC, 2001). Therefore, daily I requirement for cows used in the current study averaged $6.75 \mathrm{mg}$ based on a mean BW of $450 \mathrm{~kg}$. Iodine intake was beyond recommendation in all 5 diets, but it was specifically concerning in the diets supplemented with 57,113 , or $176 \mathrm{~g} / \mathrm{d}$ of ASCO meal as they resulted in 325, 620, and $921 \%$ of I above the requirement, respectively. Despite excessive I intake, the maximal tolerable concentration of I, which is estimated to be at $50 \mathrm{mg} / \mathrm{kg}$ of DMI (NRC, 2005), was not reached even in the diet supplemented with $176 \mathrm{~g} / \mathrm{d}$ of ASCO meal (mean $=3.28 \mathrm{mg}$ of I $/ \mathrm{kg}$ of DMI or $15.3 \mathrm{mg}$ of I intake $/ 100 \mathrm{~kg}$ of BW). However, I toxicity (Olson et al., 1984) and enlargement of the thyroid gland (i.e., hyperplastic goiter; Ong et al., 2014) were observed with 12 to $100 \mathrm{mg}$ of I intake/100 $\mathrm{kg}$ of BW and 7.5 to $12.5 \mathrm{mg}$ of I intake/100 kg of BW in dairy cows, respectively.

Serum I concentration, I excretion in feces and urine, and I concentration and secretion in milk followed I intake and increased linearly $(P<0.001)$ in cows fed with incremental amounts of ASCO meal (Table 4). Milk I concentration in cows supplemented with ASCO meal averaged $995 \mu \mathrm{g} / \mathrm{L}$ and was $99 \%$ greater than the $500 \mu \mathrm{g} / \mathrm{L}$ threshold of I considered safe for human consumption (EFSA, 2013). Miller and Swanson (1973) reported that concentration of I in serum, milk, urine, and feces all increased proportionally to the amount of ethylenediamine dihydriodide $(0,50,100,200,500$, and $1,000 \mathrm{mg} / \mathrm{d}$ ) fed to dairy cows. However, the intake of I in cows fed diets supplemented with ASCO meal was lower than the I output in feces, urine, and milk in our study. This suggests that I excretion may have been overestimated due to the use of markers to estimate urinary volume (i.e., creatinine) and fecal output of DM (i.e., indigestible ADF). Therefore, absolute values of fecal and urinary I excretion should be interpreted cautiously. Nevertheless, the relationship between I intake and I excretion in feces resulted in the greatest slope (Supplemental Table S3, https://figshare.com/ articles/dataset/Supplemental_Table_S3/19141679; Brito, 2022c), indicating that the digestive tract appears to be the main route for I excretion.

According to Miller et al. (1975), between 70 to $90 \%$ of the I consumed is absorbed directly from the rumen, reticulum, and omasum, with iodide being extensively recycled to the abomasum following administration of radioiodine. In addition, hormonal I secreted in the small intestine via recycling of $\mathrm{T}_{4}$ through the bile further contributes to fecal I excretion (Miller et al., 1975). Miller et al. (1975) reported that, on average, 30 and $40 \%$ of the total daily I intake was reported to be excreted in feces and urine, respectively, and only $8 \%$ was transferred to milk in dairy cows fed $<10 \mu \mathrm{g}$ of $\mathrm{I} / \mathrm{kg}$ of BW. However, urinary volume and fecal DM excretion were not directly quantified via total collection or estimated by markers in the studies used in the review of Miller et al. (1975). Miller and Swanson (1973) demonstrated that about $20 \%$ of I was recovered in feces of lactating dairy cows intravenously dosed with radioiodine, thus reinforcing that I is efficiently recycled via the gastrointestinal tract even when supplied parenterally.

Iodine is required for the synthesis of the thyroid hormones $\mathrm{T}_{3}$ and $\mathrm{T}_{4}$, which are involved in energy metabolism and are released in response to TSH produced 
by the pituitary gland in the brain (NRC, 2005; Goff, 2018). Therefore, increased I intake due to ASCO meal supplementation may promote changes in circulating $\mathrm{TSH}, \mathrm{T}_{3}$, and $\mathrm{T}_{4}$. The serum concentration of TSH tended $(P=0.06)$ to respond quadratically (Table 4 ) in response to increasing levels of ASCO meal supplementation. Specifically, serum TSH increased from $2.62 \mathrm{ng} / \mathrm{mL}$ in the control diet to $3.07 \mathrm{ng} / \mathrm{mL}(56 \mathrm{~g} / \mathrm{d}$ of ASCO meal) and $3.08 \mathrm{ng} / \mathrm{mL}(113 \mathrm{~g} / \mathrm{d}$ of ASCO meal) but dropped to $2.84 \mathrm{ng} / \mathrm{mL}$ with the greatest supplementation level (i.e., $176 \mathrm{~g} / \mathrm{d}$; Table 4). These changes in TSH concentrations may not be biologically important because neither $T_{3}$ nor $T_{4}$ values were affected by ASCO meal despite linear increases in I intake and serum concentration of I (Table 4). Serum concentrations of TSH and total and free $\mathrm{T}_{3}$ and $\mathrm{T}_{4}$ were not affected by various amounts (up to $176 \mathrm{~g} / \mathrm{d}$ ) of ASCO meal supplemented to lactating dairy cows in previous studies (Antaya et al., 2015; Sorge et al., 2016b; Iannaccone et al., 2019). In contrast, Antaya et al. (2019) observed a diet $\times$ period interaction for the serum concentration of $\mathrm{T}_{3}$, which was not affected by diets during periods 1 and 2 but decreased $14 \%$ in period 3, thus coinciding with cows being fed ASCO meal $(113 \mathrm{~g} / \mathrm{d})$ for approximately $80 \mathrm{~d}$. This indicates that thyroid hormones concentrations can be affected when I is fed above requirement for an extended period of time (Antaya et al., 2019) compared with shorter intake periods like in the current study and others (i.e., Antaya et al., 2015; Sorge et al., 2016b; Iannaccone et al., 2019).

Brown seaweeds are known to accumulate more As than their red and green counterparts (Taylor and Jackson, 2016; Biancarosa et al., 2018). However, within brown seaweed species, ASCO is the one with lowest ability to accumulate As (Taylor and Jackson, 2016). Previous studies further revealed that As from ASCO is mostly found in the organic form (Taylor and Jackson, 2016), which is considered less toxic than inorganic As (NRC, 2001). We observed a linear increase $(P<0.001)$ in the intake of As in cows fed incremental amounts of ASCO meal (Table 4). Fecal excretion of As followed As intake and increased linearly $(P<0.001)$ in response to ASCO meal supplementation (Table 4). Contrarily, urinary As excretion, concentration and yield of milk As, and serum As concentration were not significantly affected by varying levels of ASCO meal (Table 4). We also observed that the slope from regressing As intake and fecal As excretion was greater than those obtained for the regressions between As intake and milk As (Supplemental Table S3), suggesting that the digestive tract is the main route for As removal. Furthermore, the slope for regressing As intake on milk As yield did not differ from zero based on the confidence interval (Supplemental Table S3), indicating that As from ASCO meal was poorly transferred to milk. In fact, Monagail et al. (2018) demonstrated, using Monte Carlo simulations, that the transfer of As from ASCO to milk was negligible and not harmful to human health.

\section{Blood Metabolites, Hormones, and Antioxidant Enzymes}

The concentration of plasma urea $\mathrm{N}$ was not significantly affected by ASCO meal supplementation (Table 5 ), which agrees with previous studies using growing lambs (Archer et al., 2007) and lactating dairy cows (Antaya et al., 2015, 2019). However, cows fed MON had greater $(P=0.04)$ plasma urea $\mathrm{N}$ concentration compared with those fed ASCO meal (Table 5), suggesting that PT from ASCO meal may have a stronger antiproteolytic activity than MON despite no differences in the concentrations of ruminal $\mathrm{NH}_{3}-\mathrm{N}$ (Table 2) and MUN (Supplemental Table S2) when comparing ASCO meal with MON. The plasma concentration of glucose was greater $(P<0.01)$ in cows supplemented with MON versus ASCO meal or MON versus the control diet, with these results in line with the increased $(P$ $\leq 0.03$ ) ruminal molar proportion of propionate in the MON diet (Table 2).

Supplementation with incremental amounts of ASCO meal decreased the serum concentration of cortisol linearly $(P=0.01$; Table 5$)$. Antaya et al. (2015) reported that the serum concentration of cortisol tended to decrease linearly in lactating dairy supplemented with the same levels of ASCO meal used herein. These results suggest that ASCO meal may attenuate stress during winter (Antaya et al., 2015) and summer (present study). In contrast, ASCO meal supplementation $(113 \mathrm{~g} / \mathrm{d})$ did not affect the serum cortisol concentration in grazing dairy cows throughout the summer season (Antaya et al., 2019). Archer et al. (2007) observed linear reductions in the plasma concentration of cortisol in lambs fed varying levels of ASCO meal $(0,6.6,13.2$, and 26.4 $\mathrm{g} / \mathrm{d}$ ) before and after forced walking, and after 4 and 8 $\mathrm{h}$ of transportation. In a follow-up experiment, Archer et al. (2008) demonstrated that the plasma concentration of cortisol tended to decrease before transportation in lambs fed $30 \mathrm{~g} / \mathrm{d}$ of ASCO meal compared with the control treatment. In both studies (Archer et al., $2007,2008)$, the plasma concentration of aldosterone decreased in response to ASCO meal supplementation, suggesting impairment of the adrenal gland function and less cortisol production. However, ASCO meal supplementation did not affect the serum concentration of aldosterone in the present study (Table 5), implying that additional factors may be involved. According to 
Table 5. Plasma and serum concentrations of urea N, glucose, and hormones, and antioxidant enzyme activities in Jersey cows supplemented with incremental amounts of Ascophyllum nodosum (ASCO) meal or monensin (MON) ${ }^{1}$

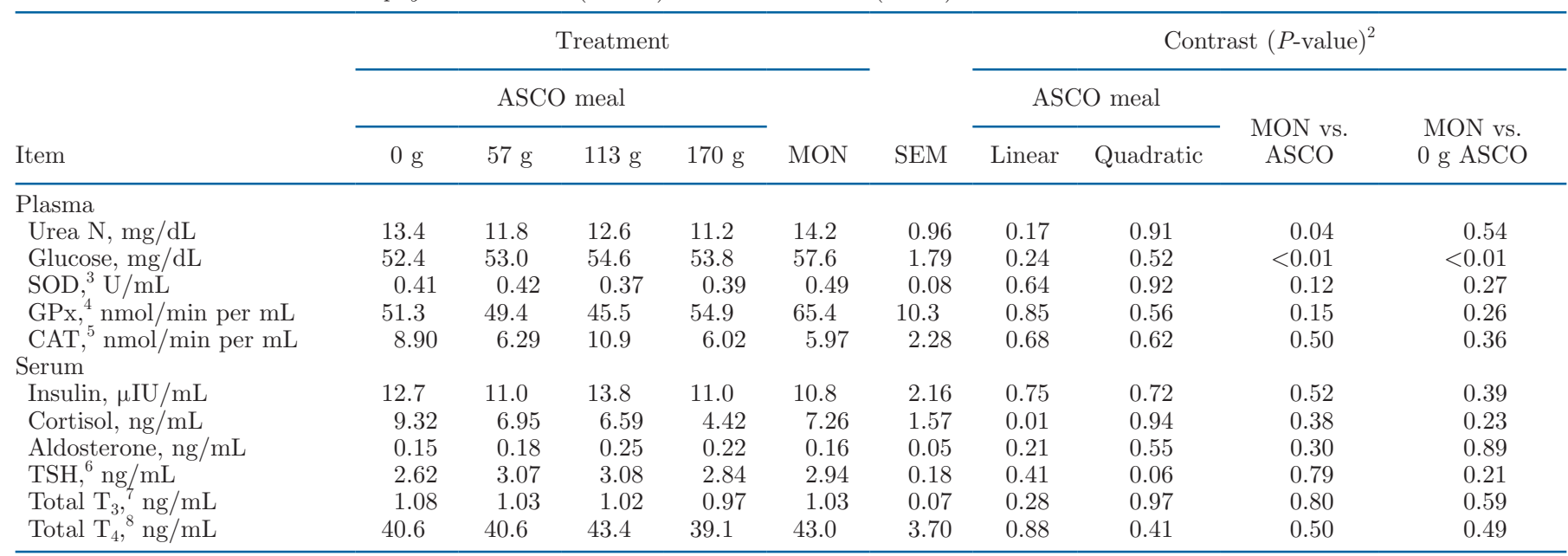

${ }^{1}$ Supplied as a medicated pellet feed $(113 \mathrm{~g} / \mathrm{d}$; Poulin Grain Inc.) to deliver $300 \mathrm{mg} / \mathrm{d}$ of monensin sodium.

${ }^{2}$ Nonorthogonal contrasts were used to compare: (1) linear and quadratic effects in response to incremental amounts of ASCO meal supplementation; (2) MON versus ASCO meal treatments (57, 113, and $170 \mathrm{~g} / \mathrm{d}$ ); and (3) MON versus the control diet (0 g/d of ASCO meal).

${ }^{3} \mathrm{SOD}=$ superoxide dismutase.

${ }^{4} \mathrm{GPx}=$ glutathione peroxidase.

${ }^{5} \mathrm{CAT}=$ catalase.

${ }^{6} \mathrm{TSH}=$ thyroid-stimulating hormone.

${ }^{7} \mathrm{~T}_{3}=$ triiodothyronine.

${ }^{8} \mathrm{~T}_{4}=$ thyroxin.

Allen et al. (2001), the mechanism underpinning how ASCO-based products alleviate cold or heat stress is not well understood, but upregulation of antioxidant enzymes appears to be implicated. Nevertheless, this suggested mechanism does not explain our cortisol results considering that ASCO meal supplementation had no effect on the plasma activities of the enzymes superoxide dismutase, glutathione peroxidase, and catalase (Table 5).

\section{CONCLUSIONS}

Supplementation with incremental amounts of ASCO meal had no effect on the total number of protozoa and bacterial $16 \mathrm{~S}$ rRNA gene copies in ruminal fluid of lactating Jersey cows. We also observed that increasing dietary levels of ASCO meal did not change bacterial diversity and taxa in ruminal fluid except for the relative abundance of Tenericutes, which decreased linearly with ASCO supplementation. Therefore, our hypothesis that ASCO meal would change ruminal bacterial diversity and taxa was mostly rejected. Feeding MON increased the ruminal molar proportion of propionate compared with the control diet $(0 \mathrm{~g} / \mathrm{d}$ of ASCO meal) or diets containing ASCO meal possibly linked to the MON effect on reducing the relative abundance of the acetate producers Rikenellaceae and Ruminococcaceae.
Milk I concentration and yield increased linearly in cows supplemented with varying amounts of ASCO meal, thus in agreement with our hypothesis. However, concentration and yield of milk As were not affected by ASCO meal supplementation. Fecal excretion of I was greater than I intake, suggesting extensive recycling of I via the gastrointestinal tract. Serum concentration of cortisol decreased linearly in response to increasing levels of ASCO meal, but we could not conclusively determine how ASCO meal affected circulating cortisol, warranting further research.

\section{ACKNOWLEDGMENTS}

This research was partially funded by the Northeast SARE (Project Number GNE15-101; Burlington, VT) and Acadian Seaplants Ltd. (Nova Scotia, Canada). Partial funding was also provided by the New Hampshire Agricultural Experiment Station (Scientific Contribution Number 2928) and the USDA-NIFA Hatch Multistate NC-2042 (Project Number NH00670-R; Kansas City, MO). Gratitude is extended to $\mathrm{CNPq}$ (Brasília, DF, Brazil) and CAPES (Brasília, DF, Brazil) for scholarships awarded to visiting professor Ronan Santana (CAPES) and graduate students Daiane Moura (CNPq) and Igor Alexandre de Souza (CAPES) who provided support during sample collec- 
tion. We also thank graduate student Caren P. Ghedini (University of New Hampshire, Durham) for her help feeding cows and collecting samples. Research support and excellent animal care of Jon Whitehouse and his crew at the University of New Hampshire Fairchild Dairy Teaching and Research Center (Durham) is sincerely appreciated. The authors have not stated any conflicts of interest.

\section{REFERENCES}

Allen, V. G., K. R. Pond, K. E. Saker, J. P. Fontenot, C. P. Bagley, R. L. Ivy, R. R. Evans, R. E. Schmidt, J. H. Fike, X. Zhang, J. Y. Ayad, C. P. Brown, M. F. Miller, J. L. Montgomery, J. Mahan, D. B. Wester, and C. Melton. 2001. Tasco: Influence of a brown seaweed on antioxidants in forages and livestock-A review. J. Anim. Sci. 79(E-Suppl):E21. https://doi.org/10.2527/jas2001.79E -SupplE21x.

Antaya, N. T., M. Ghelichkhan, A. B. D. Pereira, K. J. Soder, and A. F. Brito. 2019. Production, milk iodine, and nutrient utilization in Jersey cows supplemented with the brown seaweed Ascophyllum nodosum (kelp meal) during the grazing season. J. Dairy Sci. 102:8040-8058. https://doi.org/10.3168/jds.2019-16478.

Antaya, N. T., K. J. Soder, J. Kraft, N. L. Whitehouse, N. E. Guindon, P. S. Erickson, A. B. Conroy, and A. F. Brito. 2015. Incremental amounts of Ascophyllum nodosum meal do not improve animal performance but do increase milk iodine output in early lactation dairy cows fed high-forage diets. J. Dairy Sci. 98:1991-2004. https: //doi.org/10.3168/jds.2014-8851.

Archer, G. S., T. H. Friend, D. Caldwell, K. Ameiss, and P. D. Krawczel. 2007. Effect of the seaweed Ascophyllum nodosum on lambs during forced walking and transport. J. Anim. Sci. 85:225-232. https://doi.org/10.2527/jas.2005-452.

Archer, G. S., T. H. Friend, D. Caldwell, K. Ameiss, P. D. Krawczel, C. Iacono, H. Keen, and T. Martin. 2008. Impacts of feeding several components of the seaweed Ascophyllum nodosum on transported lambs. Anim. Feed Sci. Technol. 140:258-271. https://doi .org/10.1016/j.anifeedsci.2007.03.003.

Bekele, A. Z., S. Koike, and Y. Kobayashi. 2011. Phylogenetic diversity and dietary association of rumen Treponema revealed using group-specific 16S rRNA gene-based analysis. FEMS Microbiol. Lett. 316:51-60. https://doi.org/10.1111/j.1574-6968.2010.02191 .x.

Belanche, A., E. Jones, I. Parveen, and C. J. Newbold. 2016a. A metagenomics approach to evaluate the impact of dietary supplementation with Ascophyllum nodosum or Laminaria digitata on rumen function in Rusitec fermenters. Front. Microbiol. 7:299. https: //doi.org/10.3389/fmicb.2016.00299.

Belanche, A., E. Ramos-Morales, and C. J. Newbold. 2016b. In vitro screening of natural feed additives from crustaceans, diatoms, seaweeds and plant extracts to manipulate rumen fermentation. J. Sci. Food Agric. 96:3069-3078. https://doi.org/10.1002/jsfa.7481.

Biancarosa, I., I. Belghit, C. G. Bruckner, N. S. Liland, R. Waagbø, H. Amlund, S. Heesch, and E. J. Lock. 2018. Chemical characterization of 21 species of marine macroalgae common in Norwegian waters: benefits of and limitations to their potential use in food and feed. J. Sci. Food Agric. 98:2035-2042. https://doi.org/10.1002/ jsfa. 8798 .

Bolger, A. M., M. Lohse, and B. Usadel. 2014. Trimmomatic: A flexible trimmer for Illumina sequence data. Bioinformatics 30:21142120. https://doi.org/10.1093/bioinformatics/btu170.

Bolyen, E., J. R. Rideout, M. R. Dillon, N. A. Bokulich, C. C. Abnet, G. A. Al-Ghalith, H. Alexander, E. J. Alm, M. Arumugam, F. Asnicar, Y. Bai, J. E. Bisanz, K. Bittinger, A. Brejnrod, C. J. Brislawn, C. T. Brown, B. J. Callahan, A. M. Caraballo-Rodríguez, J. Chase, E. K. Cope, R. Da Silva, C. Diener, P. C. Dorrestein, G. M. Douglas, D. M. Durall, C. Duvallet, C. F. Edwardson, M. Ernst, M. Estaki, J. Fouquier, J. M. Gauglitz, S. M. Gibbons,
D. L. Gibson, A. Gonzalez, K. Gorlick, J. Guo, B. Hillmann, S. Holmes, H. Holste, C. Huttenhower, G. A. Huttley, S. Janssen, A. K. Jarmusch, L. Jiang, B. D. Kaehler, K. B. Kang, C. R. Keefe, P. Keim, S. T. Kelley, D. Knights, I. Koester, T. Kosciolek, J. Kreps, M. G. I. Langille, J. Lee, R. Ley, Y.-X. Liu, E. Loftfield, C. Lozupone, M. Maher, C. Marotz, B. D. Martin, D. McDonald, L. J. McIver, A. V. Melnik, J. L. Metcalf, S. C. Morgan, J. T. Morton, A. T. Naimey, J. A. Navas-Molina, L. F. Nothias, S. B. Orchanian, T. Pearson, S. L. Peoples, D. Petras, M. L. Preuss, E. Pruesse, L. B. Rasmussen, A. Rivers, M. S. Robeson II, P. Rosenthal, N. Segata, M. Shaffer, A. Shiffer, R. Sinha, S. J. Song, J. R. Spear, A. D. Swafford, L. R. Thompson, P. J. Torres, P. Trinh, A. Tripathi, P. J. Turnbaugh, S. Ul-Hasan, J. J. J. van der Hooft, F. Vargas, Y. Vázquez-Baeza, E. Vogtmann, M. von Hippel, W. Walters, Y. Wan, M. Wang, J. Warren, K. C. Weber, C. H. D. Williamson, A. D. Willis, Z. Z. Xu, J. R. Zaneveld, Y. Zhang, Q. Zhu, R. Knight, and J. G. Caporaso. 2019. Reproducible, interactive, scalable and extensible microbiome data science using QIIME 2. Nat. Biotechnol. 37:852-857. https://doi.org/10.1038/s41587-019-0209-9.

Brito, A. 2022a. Supplemental Table S1. figshare. Dataset. https://doi .org/10.6084/m9.figshare.19140212.v2.

Brito, A. 2022b. Supplemental Table S2. figshare. Dataset. https://doi .org/10.6084/m9.figshare.19140275.v1.

Brito, A. 2022c. Supplemental Table S3. figshare. Dataset. https://doi .org/10.6084/m9.figshare.19141679.v1.

Brito, A. F., and L. H. P. Silva. 2020. Symposium review: Comparisons of feed and milk nitrogen efficiency and carbon emissions in organic versus conventional dairy production systems. J. Dairy Sci. 103:5726-5739. https://doi.org/10.3168/jds.2019-17232.

Broderick, G. A. 2004. Effect of low level monensin supplementation on the production of dairy cows fed alfalfa silage. J. Dairy Sci. 87:359-368. https://doi.org/10.3168/jds.S0022-0302(04)73175-6.

Brown, D. R. 2018. Tenericutes. Pages 1-3 in Bergey's Manual of Systematics of Archaea and Bacteria. W. B. Whitman, ed. John Wiley \& Sons.

Callahan, B. J., P. J. McMurdie, M. J. Rosen, A. W. Han, A. J. Johnson, and S. P. Holmes. 2016. DADA2: High resolution sample inference from Illumina amplicon data. Nat. Methods 13:581-583. https://doi.org/10.1038/nmeth.3869.

Caporaso, J. G., C. L. Lauber, W. A. Walters, D. Berg-Lyons, C. A. Lozupone, P. J. Turnbaugh, N. Fierer, and R. Knight. 2011. Global patterns of $16 \mathrm{~S}$ rRNA diversity at a depth of millions of sequences per sample. Proc. Natl. Acad. Sci. USA 108(Supplement_1):4516-4522. https://doi.org/10.1073/pnas.1000080107.

Chen, X. B., Y. K. Chen, M. F. Franklin, E. R. Ørskov, and W. J. Shand. 1992. The effect of feed intake and body weight on purine derivative excretion and microbial protein supply in sheep. J. Anim. Sci. 70:1534-1542. https://doi.org/10.2527/1992.7051534x.

Chizzotti, M. L., S. C. Valadares Filho, R. F. D. Valadares, F. H. M. Chizzotti, and L. O. Tedeschi. 2008. Determination of creatinine excretion and evaluation of spot urine sampling in Holstein cattle. Livest. Sci. 113:218-225. https://doi.org/10.1016/j.livsci.2007.03 .013 .

Clemmons, B. A., C. Martino, L. G. Schneider, J. Lefler, M. M. Embree, and P. R. Myer. 2019. Temporal stability of the ruminal bacterial communities in beef steers. Sci. Rep. 9:9522. https://doi .org/10.1038/s41598-019-45995-2.

Cochran, R. C., D. C. Adams, J. D. Wallace, and M. L. Galyean. 1986 Predicting digestibility of different diets with internal markers: Evaluation of four potential markers. J. Anim. Sci. 63:1476-1483. https://doi.org/10.2527/jas1986.6351476x.

Connan, S., F. Goulard, V. Stiger, E. Deslandes, and E. Ar Gall. 2004. Interspecific and temporal variation in phlorotannin levels in an assemblage of brown algae. Bot. Mar. 47:410-416. https://doi.org/ 10.1515/BOT.2004.057.

Dehority, B. A. 2005. Effect of $\mathrm{pH}$ on viability of Entodinium caudatum, Entodinium exiguum, Epidinium caudatum, and Ophryoscolex purkynjei in vitro. J. Eukaryot. Microbiol. 52:339-342. https://doi .org/10.1111/j.1550-7408.2005.00041.x.

DeSantis, T. Z., P. Hugenholtz, N. Larsen, M. Rojas, E. L. Brodie, K. Keller, T. Huber, D. Dalevi, P. Hu, and G. L. Andersen. 
2006. Greengenes, a chimera-checked $16 \mathrm{~S}$ rRNA gene database and workbench compatible with ARB. Appl. Environ. Microbiol. 72:5069-5072. https://doi.org/10.1128/AEM.03006-05.

Duffield, T. F., A. R. Rabiee, and I. J. Lean. 2008a. A meta-analysis of the impact of monensin in lactating dairy cattle. Part 1. Metabolic effects. J. Dairy Sci. 91:1334-1346. https://doi.org/10.3168/ jds.2007-0607.

Duffield, T. F., A. R. Rabiee, and I. J. Lean. 2008b. A meta-analysis of the impact of monensin in lactating dairy cattle. Part 2. Production effects. J. Dairy Sci. 91:1347-1360. https://doi.org/10.3168/ jds.2007-0608.

EFSA. 2013. Scientific opinion on the safety and efficacy of iodine compounds (E2) as feed additives for all animal species: Calcium iodate anhydrous and potassium iodide, based on a dossier submitted by Ajay Europe SARL. EFSA J. 11:3099. https://doi.org/10 .2903/j.efsa.2013.3099.

Esquivel-Elizondo, S., Z. E. Ilhan, E. I. Garcia-Peña, and R. Krajmalnik-Brown. 2017. Insights into butyrate production in a controlled fermentation system via gene predictions. mSystems 2:e00051. https://doi.org/10.1128/mSystems.00051-17.

Evans, F. D., and A. T. Critchley. 2014. Seaweeds for animal production use. J. Appl. Phycol. 26:891-899. https://doi.org/10.1007/ s10811-013-0162-9.

Fike, J. H., K. E. Saker, S. F. O'Keefe, N. G. Marriott, D. L. Ward, J. P. Fontenot, and H. P. Veit. 2005. Effects of Tasco (a seaweed extract) and heat stress on $\mathrm{N}$ metabolism and meat fatty acids in wether lambs fed hays containing endophyte-infected fescue. Small Rumin. Res. 60:237-245. https://doi.org/10.1016/j.smallrumres 2004.12.007.

Fisher, R. A., A. S. Corbet, and C. B. Williams. 1943. The relation between the number of species and the number of individuals in a random sample of an animal population. J. Anim. Ecol. 12:42-58. https://doi.org/10.2307/1411.

Goff, J. P. 2018. Invited review: Mineral absorption mechanisms, mineral interactions that affect acid-base and antioxidant status, and diet considerations to improve mineral status. J. Dairy Sci. 101:2763-2813. https://doi.org/10.3168/jds.2017-13112.

Hardie, C. A., M. Wattiaux, M. Dutreuil, R. Gildersleeve, N. S. Keuler, and V. E. Cabrera. 2014. Feeding strategies on certified organic dairy farms in Wisconsin and their effect on milk production and income over feed costs. J. Dairy Sci. 97:4612-4623. https://doi .org/10.3168/jds.2013-7763.

Huhtanen, P., K. Kaustell, and S. Jaakkola. 1994. The use of internal markers to predict total digestibility and duodenal flow of nutrients in cattle given six different diets. Anim. Feed Sci. Technol. 48:211-227. https://doi.org/10.1016/0377-8401(94)90173-2.

Iannaccone, M., A. Ianni, R. Elgendy, C. Martino, M. Giantin, L. Cerretani, M. Dacasto, and G. Martino. 2019. Iodine supplemented diet positively affect immune response and dairy product quality in Friesian cows. Animals (Basel) 9:866. https://doi.org/10.3390/ ani9110866.

Ipharraguerre, I. R., and J. H. Clark. 2003. Usefulness of ionophores for lactating dairy cows: A review. Anim. Feed Sci. Technol. 106:39-57. https://doi.org/10.1016/S0377-8401(03)00065-8.

Ji, S., H. Zhang, H. Yan, A. Azarfar, H. Shi, G. Alugongo, S. Li, Z. Cao, and Y. Wang. 2017. Comparison of rumen bacteria distribution in original rumen digesta, rumen liquid and solid fractions in lactating Holstein cows. J. Anim. Sci. Biotechnol. 8:16. https://doi .org/10.1186/s40104-017-0142-z.

Jiménez, J. T., S. O'Connell, H. Lyons, B. Bradley, and M. Hall. 2010. Antioxidant, antimicrobial, and tyrosinase inhibition activities of acetone extract of Ascophyllum nodosum. Chem. Pap. 64:434-442. https://doi.org/10.2478/s11696-010-0024-8.

Lengowski, M. B., M. Witzig, J. Möhring, G. M. Seyfang, and M. Rodehutscord. 2016. Effects of corn silage and grass silage in ruminant rations on diurnal changes of microbial populations in the rumen of dairy cows. Anaerobe 42:6-16. https://doi.org/10.1016/ j.anaerobe.2016.07.004.

Leupp, J. L., J. S. Caton, S. A. Soto-Navarro, and G. P. Lardy. 2005. Effects of cooked molasses blocks and fermentation extract or brown seaweed meal inclusion on intake, digestion, and microbial efficiency in steers fed low-quality hay. J. Anim. Sci. 83:2938-2945. https://doi.org/10.2527/2005.83122938x.

Liu, J., M. Zhang, C. Xue, W. Zhu, and S. Mao. 2016. Characterization and comparison of the temporal dynamics of ruminal bacterial microbiota colonizing rice straw and alfalfa hay within ruminants. J. Dairy Sci. 99:9668-9681. https://doi.org/10.3168/jds .2016-11398

Machado, M. G., E. Detmann, H. C. Mantovani, S. C. Valadares Filho, C. B. P. Bento, M. I. Marcondes, and A. S. Assunção. 2016. Evaluation of the length of adaptation period for changeover and crossover nutritional experiments with cattle fed tropical forage-based diets. Anim. Feed Sci. Technol. 222:132-148. https://doi.org/10 .1016/j.anifeedsci.2016.10.009.

Makkar, H. P. S., G. Tran, V. Heuzé, S. Giger-Reverdin, M. Lessire, F. Lebas, and P. Ankers. 2016. Seaweeds for livestock diets: A review. Anim. Feed Sci. Technol. 212:1-17. https://doi.org/10.1016/ j.anifeedsci.2015.09.018.

McGarvey, J. A., S. Place, J. Palumbo, R. Hnasko, and F. Mitloehner. 2019. Dosage-dependent effects of monensin on the rumen microbiota of lactating dairy cattle. MicrobiologyOpen 8:e783. https:// doi.org/10.1002/mbo3.783.

Miller, J. K., and E. W. Swanson. 1973. Metabolism of ethylenediaminedihydriodide and sodium or potassium iodide by dairy cows. J. Dairy Sci. 56:378-384. https://doi.org/10.3168/jds.S0022 -0302(73)85181-1.

Miller, J. K., E. W. Swanson, and G. E. Spalding. 1975. Iodine absorption, excretion, recycling, and tissue distribution in the dairy cow. J. Dairy Sci. 58:1578-1593. https://doi.org/10.3168/jds.S0022 $-0302(75) 84753-9$

Monagail, M., E. Cummins, R. Bermejo, E. Daly, D. Costello, and L. Morrison. 2018. Quantification and feed to food transfer of total and inorganic arsenic from a commercial seaweed feed. Environ. Int. 118:314-324. https://doi.org/10.1016/j.envint.2018.05.032.

Mullins, C. R., L. K. Mamedova, A. J. Carpenter, Y. Ying, M. S. Allen, I. Yoon, and B. J. Bradford. 2013. Analysis of rumen microbial populations in lactating dairy cattle fed diets varying in carbohydrate profiles and Saccharomyces cerevisiae fermentation product. J. Dairy Sci. 96:5872-5881. https://doi.org/10.3168/jds .2013-6775.

National Research Council (NRC). 2001. Nutrient Requirements of Dairy Cattle. 7th rev. ed. Natl. Acad. Press. https://doi.org/10 $.17226 / 9825$.

National Research Council (NRC). 2005. Mineral Tolerance of Domestic Animals. 2nd rev. ed. Natl. Acad. Press. https://doi.org/ $10.17226 / 25$.

Olson, W. G., J. B. Stevens, J. Anderson, and D. W. Haggard. 1984. Iodine toxicosis in six herds of dairy cattle. J. Am. Vet. Med. Assoc. $184: 179-181$

Ong, C. B., T. H. Herdt, and S. D. Fitzgerald. 2014. Hyperplastic goiter in two adult dairy cows. J. Vet. Diagn. Invest. 26:810-814. https://doi.org/10.1177/1040638714554441

Pedregosa, F., G. Varoquaux, A. Gramfort, V. Michel, B. Thirion, O. Grisel, M. Blondel, P. Prettenhofer, R. Weiss, V. Dubourg, J. Vanderplas, A. Passos, D. Cournapeau, M. Brucher, M. Perrot, and É. Duchesnay. 2011. Scikit-learn: Machine learning in Python. J. Mach. Learn. Res. 12:2825-2830.

Pompeu, L. B., J. E. Williams, D. E. Spiers, R. L. Weaber, M. R. Ellersieck, K. M. Sargent, N. P. Feyerabend, H. L. Vellios, and F. Evans. 2011. Effect of Ascophyllum nodosum on alleviation of heat stress in dairy cows. Prof. Anim. Sci. 27:181-189. https://doi.org/ 10.15232/S1080-7446(15)30472-1.

Quast, C., E. Pruesse, P. Yilmaz, J. Gerken, T. Schweer, P. Yarza, J. Peplies, and F. O. Glöckner. 2013. The SILVA ribosomal RNA gene database project: Improved data processing and web-based tools. Nucleic Acids Res. 41(D1):D590-D596. https://doi.org/10 $.1093 /$ nar/gks1219.

Ren, Q., H. Si, X. Yan, C. Liu, L. Ding, R. Long, Z. Li, and Q. Qiu. 2020. Bacterial communities in the solid, liquid, dorsal, and ventral epithelium fractions of yak (Bos grunniens) rumen. MicrobiologyOpen 9:e963. https://doi.org/10.1002/mbo3.963. 
Reveneau, C., S. K. R. Karnati, E. R. Oelker, and J. L. Firkins. 2012. Interaction of unsaturated fat or coconut oil with monensin in lactating dairy cows fed 12 times daily. I. Protozoal abundance, nutrient digestibility, and microbial protein flow to the omasum. J. Dairy Sci. 95:2046-2060. https://doi.org/10.3168/jds.2011-4887.

Roque, B. M., J. K. Salwen, R. Kinley, and E. Kebreab. 2019. Inclusion of Asparagopsis armata in lactating dairy cows' diet reduces enteric methane emission by over 50 percent. J. Clean. Prod. 234:132-138. https://doi.org/10.1016/j.jclepro.2019.06.193.

Russell, J. B. 1987. A proposed mechanism of monensin action in inhibiting ruminant bacterial growth: Effects on ion flux and protonmotive force. J. Anim. Sci. 64:1519-1525. https://doi.org/10 $.2527 /$ jas1987.6451519x

Schären, M., C. Drong, K. Kiri, S. Riede, M. Gardener, U. Meyer, J. Hummel, T. Urich, G. Breves, and S. Dänicke. 2017. Differential effects of monensin and a blend of essential oils on rumen microbiota composition of transition dairy cows. J. Dairy Sci. 100:27652783. https://doi.org/10.3168/jds.2016-11994.

Shannon, C. E., and W. Weaver. 1949. The Mathematical Theory of Communication. University of Illinois Press.

Simpson, E. H. 1949. Measurement of diversity. Nature 163:688. https: //doi.org/10.1038/163688a0.

Snider, M. A., S. E. Ziegler, H. M. Darby, K. J. Soder, A. F. Brito, B. Beidler, S. Flack, S. L. Greenwood, and M. T. Niles. 2021. An overview of organic, grassfed dairy farm management and factors related to higher milk production. Renew. Agric. Food Syst. 2021:1-9. https://doi.org/10.1017/S1742170521000284.

Sorge, U. S., M. Henriksen, A. Bastan, N. Cremers, K. Olsen, and B. A. Crooker. 2016b. Short communication: Iodine concentrations in serum, milk, and tears after feeding Ascophyllum nodosum to dairy cows-A pilot study. J. Dairy Sci. 99:8472-8476. https://doi.org/ 10.3168/jds.2015-10810.

Sorge, U. S., R. Moon, L. J. Wolff, L. Michels, S. Schroth, D. F. Kelton, and B. Heins. 2016a. Management practices on organic and conventional dairy herds in Minnesota. J. Dairy Sci. 99:3183-3192. https://doi.org/10.3168/jds.2015-10193.

Stern, J. L., A. E. Hagerman, P. D. Steinberg, F. C. Winter, and J. A. Estes. 1996. A new assay for quantifying brown algal phlotorotannins and comparisons to previous methods. J. Chem. Ecol. 22:1273-1293. https://doi.org/10.1007/BF02266965.
Svensson, C. J., H. Pavia, and G. B. Toth. 2007. Do plant density, nutrient availability, and herbivore grazing interact to affect phlorotannin plasticity in the brown seaweed Ascophyllum nodosum. Mar. Biol. 151:2177-2181. https://doi.org/10.1007/s00227-007-0649-5.

Taylor, V. F., and B. P. Jackson. 2016. Concentrations and speciation of arsenic in New England seaweed species harvested for food and agriculture. Chemosphere 163:6-13. https://doi.org/10.1016/j .chemosphere.2016.08.004.

Toth, G. B., O. Langhamer, and H. Pavia. 2005. Inducible and constitutive defenses of valuable seaweed tissues: Consequences for herbivore fitness. Ecology 86:612-618. https://doi.org/10.1890/04 -0484 .

Wang, Y., T. W. Alexander, and T. A. McAllister. 2009a. In vitro effects of phlorotannins from Ascophyllum nodosum (brown seaweed) on rumen bacterial populations and fermentation. J. Sci. Food Agric. 89:2252-2260. https://doi.org/10.1002/jsfa.3717.

Wang, Y., Z. Xu, S. J. Bach, and T. A. McAllister. 2008. Effects of phlorotannins from Ascophyllum nodosum (brown seaweed) on in vitro ruminal digestion of mixed forage or barley grain. Anim. Feed Sci. Technol. 145:375-395. https://doi.org/10.1016/j .anifeedsci.2007.03.013.

Wang, Y., Z. Xu, S. J. Bach, and T. A. McAllister. 2009b. Sensitivity of Escherichia coli to seaweed (Ascophyllum nodosum) phlorotannins and terrestrial tannins. Asian-Australas. J. Anim. Sci 22:238-245. https://doi.org/10.5713/ajas.2009.80213.

Yang, C. M., and J. B. Russell. 1993. The effect of monensin supplementation on ruminal ammonia accumulation in vivo and the numbers of amino acid-fermenting bacteria. J. Anim. Sci. 71:34703476. https://doi.org/10.2527/1993.71123470x.

Zhang, J., K. Kobert, T. Flouri, and A. Stamatakis. 2014. PEAR: A fast and accurate Illumina Paired-End Read Merger. Bioinformatics 30:614-620. https://doi.org/10.1093/bioinformatics/btt593.

Zhou, M., M. Hünerberg, Y. Chen, T. Reuter, T. A. McAllister, F. Evans, A. T. Critchley, and L. L. Guan. 2018. Air-dried brown seaweed, Ascophyllum nodosum, alters the rumen microbiome in a manner that changes rumen fermentation profiles and lowers the prevalence of foodborne pathogens. MSphere 3:e00017-18. https:/ /doi.org/10.1128/mSphere.00017-18 